\title{
Effectiveness of low-level laser therapy in accelerating the orthodontic tooth movement: A systematic review and meta-analysis
}

\section{Skuteczność terapii laserem małej mocy w przyspieszaniu ortodontycznych przesunięć zębowych - systematyczny przegląd piśmiennictwa i metaanaliza}

\author{
Wesam Mhd Mounir Bakdach ${ }^{B-D, F}$, Rania Hadad ${ }^{A, C, E, F}$ \\ Department of Orthodontics, Faculty of Dentistry, University of Damascus, Syria \\ A - research concept and design; B - collection and/or assembly of data; $C$ - data analysis and interpretation; \\ $D$ - writing the article; $E$ - critical revision of the article; $F$ - final approval of the article
}

Address for correspondence

Wesam Mhd Mounir Bakdach

E-mail: bakdach-wm@hotmail.com

Funding sources

None declared

Conflict of interest

None declared

Received on July 19, 2019

Reviewed on August 26, 2019

Accepted on September 18, 2019

Published online on March 31, 2020

Cite as

Bakdach WMM, Hadad R. Effectiveness of low-level laser therapy in accelerating the orthodontic tooth movement: A systematic review and meta-analysis. Dent Med Probl. 2020;57(1):73-94. doi:10.17219/dmp/112446

DOI

$10.17219 / \mathrm{dmp} / 112446$

Copyright

(c) 2020 by Wroclaw Medical University

This is an article distributed under the terms of the

Creative Commons Attribution 3.0 Unported License (CC BY 3.0)

(https://creativecommons.org/licenses/by/3.0/)

\begin{abstract}
Objectives. The aim of the paper was to appraise the current evidence of the effectiveness of low-level laser therapy (LLLT) in accelerating the tooth movement.

Methods. A comprehensive search was performed in 9 databases up to June 2019. Only randomized controlled trials (RCTS) were included. The risk of bias was assessed using the Cochrane Collaboration tool. The quantitative data synthesis was attainable only for the studies evaluating the effect of laser on canine retraction; the qualitative description was used for the rest of the studies. The overall quality of evidence was rated using the Grading of Recommendations Assessment, Development and Evaluation (GRADE) criteria.

Results. A total of 25 RCTs were included in this review. The radiated upper canines showed a greater retraction $-0.50 \mathrm{~mm}$ and $0.49 \mathrm{~mm}$ at months 2 and 3 , respectively. The radiated lower canines showed a greater retraction $-0.28 \mathrm{~mm}$ and $0.52 \mathrm{~mm}$ at months 2 and 3 , respectively. No statistically significant differences were observed among the upper and lower canines after the $1^{\text {st }}$ month of retraction. When the GRADE approach was utilized, the overall quality of evidence limited confidence in the estimates. The qualitative description revealed enhanced tooth movement when LLLT was applied. The attrition bias was the main risk factor affecting the methodology of the studies.

Conclusions. Low-level laser therapy can speed up the rate of the tooth movement. However, the overall quality of evidence ranged from low to very low and the clinical significance of the obtained statistically significant differences is questionable. Hence, more precise studies are needed. As discussed in this review, it is highly recommended to express and compare the laser dosage with the total number of joules applied per month rather than the previously used $\mathrm{J} / \mathrm{cm}^{2}$. Moreover, the previous recommendation indicating that lower energy densities $\left(2.5,5\right.$ and $\left.8 \mathrm{~J} / \mathrm{cm}^{2}\right)$ are more effective than 20 and $25 \mathrm{~J} / \mathrm{cm}^{2}$ is misleading. Key words: orthodontics, acceleration, lasers, low-level laser therapy
\end{abstract} Słowa kluczowe: ortodoncja, przyspieszenie, lasery, terapia laserem małej mocy 


\section{Introduction}

The primary objective of orthodontic treatment is usually to achieve an optimal occlusion with minimal complications within a relatively short period of time. ${ }^{1}$ According to a recent systematic review of 22 studies involving 1,089 participants, the mean duration of comprehensive orthodontic treatment with a fixed appliance is 19.9 months. $^{2}$ This long treatment duration is associated with an increased risk of developing white spots, caries, gingivitis, and root resorption. ${ }^{3}$ Therefore, accelerating the tooth movement, which leads to a reduction in the duration and complications of the treatment, is desirable for both patients and orthodontists.

Over the last decade, numerous studies have been conducted to investigate the efficacy of different interventions in speeding up the tooth movement. One of these interventions is low-level laser therapy (LLLT). Initially, histological research showed that LLLT contributes to inducing remodeling processes in the alveolar bone by increasing the numbers of osteoblasts and osteoclasts., ${ }^{4,5}$ In consequence, an exponential growth in the number of studies conducted to investigate the effectiveness of laser treatment in accelerating the tooth movement has become apparent. Interestingly, LLLT enjoys high patient acceptability and can be easily utilized, especially with the availability of small portable devices. ${ }^{6}$

Electronic literature searches in the PubMed and Scopus databases have yielded some systematic reviews that also concern this issue. Ge et al. demonstrated that LLLT might speed up the tooth movement, adding that relatively low energy densities $\left(2.5,5\right.$ and $\left.8 \mathrm{~J} / \mathrm{cm}^{2}\right)$ are more effective than 20 or $25 \mathrm{~J} / \mathrm{cm}^{2}$ and higher. ${ }^{7}$ de Almeida et al. concluded that there was no evidence showing that the use of laser therapy can accelerate the induced tooth movement. ${ }^{8}$ Imani et al. found that LLLT could increase the rate of the orthodontic movement. ${ }^{9}$ Those differing conclusions in previous publications could be ascribed to variations in review methodology, the number of studies included and the publication dates. Hence, the objective of this review was to provide an updated assessment of the current scientific evidence concerning the efficacy of utilizing LLLT in the acceleration of the tooth movement.

\section{Methods}

\section{Research question}

The research question of whether or not LLLT accelerates the tooth movement was defined according to the PICOS format:

- Participants: Healthy male and female patients (at least 10 patients in each study) at any age and of any ethnic group who underwent orthodontic treatment;

- Interventions: Orthodontic treatment assisted by LLLT in order to accelerate the tooth movement;
- Comparisons: Orthodontic treatment without laser therapy;

- Outcomes: The rate of tooth movement (millimeters of tooth movement per time period) or any equivalent measurement indicating the efficacy of the intervention used;

- Study design: Only randomized controlled trials (RCTs) were included in this review in order to minimize confounding factors and to reduce bias.

\section{Search strategy}

A comprehensive electronic search was performed independently and in duplicate by the authors, with no limitations on language, year or publication status, from the inception to June 2019 in the following databases: the Cochrane Central Register of Controlled Trials (CENTRAL), Scopus, Trip, CINAHL via EBSCO, PubMed, OpenGrey (for grey literature), and ProQuest (for dissertations and theses). The bibliographies of the included studies and relevant reviews were screened for possible further studies. Ongoing trials were also checked through the World Health Organization (WHO) International Clinical Trials Registry Platform (ICTRP) Search Portal and ClinicalTrials.gov. More details on the electronic search strategy can be found in Supplementary Table 1.

\section{Study selection and data extraction}

The 2 authors independently assessed the studies identified during the search. Initially, a screening process was carried out by assessing titles and abstracts to identify potentially relevant articles. Then, the full-text copies of potentially relevant studies were assessed and subjected to the eligibility criteria. At this stage, to avoid any conflict of interest or any possible bias, a blinding was performed by masking the authors' and the journals' names. Any disagreements between the 2 reviewers were resolved through discussion and consensus.

Finally, information was extracted from the studies, including the authors' names, setting, PICOS data, followup period, and main findings. When doubtful information was found, the corresponding authors of the studies were contacted for clarification.

\section{Assessing the risk of bias of the included studies}

The risk of bias of the included studies was assessed independently by the 2 authors using the Cochrane Collaboration tool for assessing the risk of bias. The following fields were described as having a high, low or unclear risk of bias: random sequence generation (selection bias); allocation concealment (selection bias); blinding of participants and personnel (performance bias); blinding of outcome assessment (detection bias); incomplete outcome 


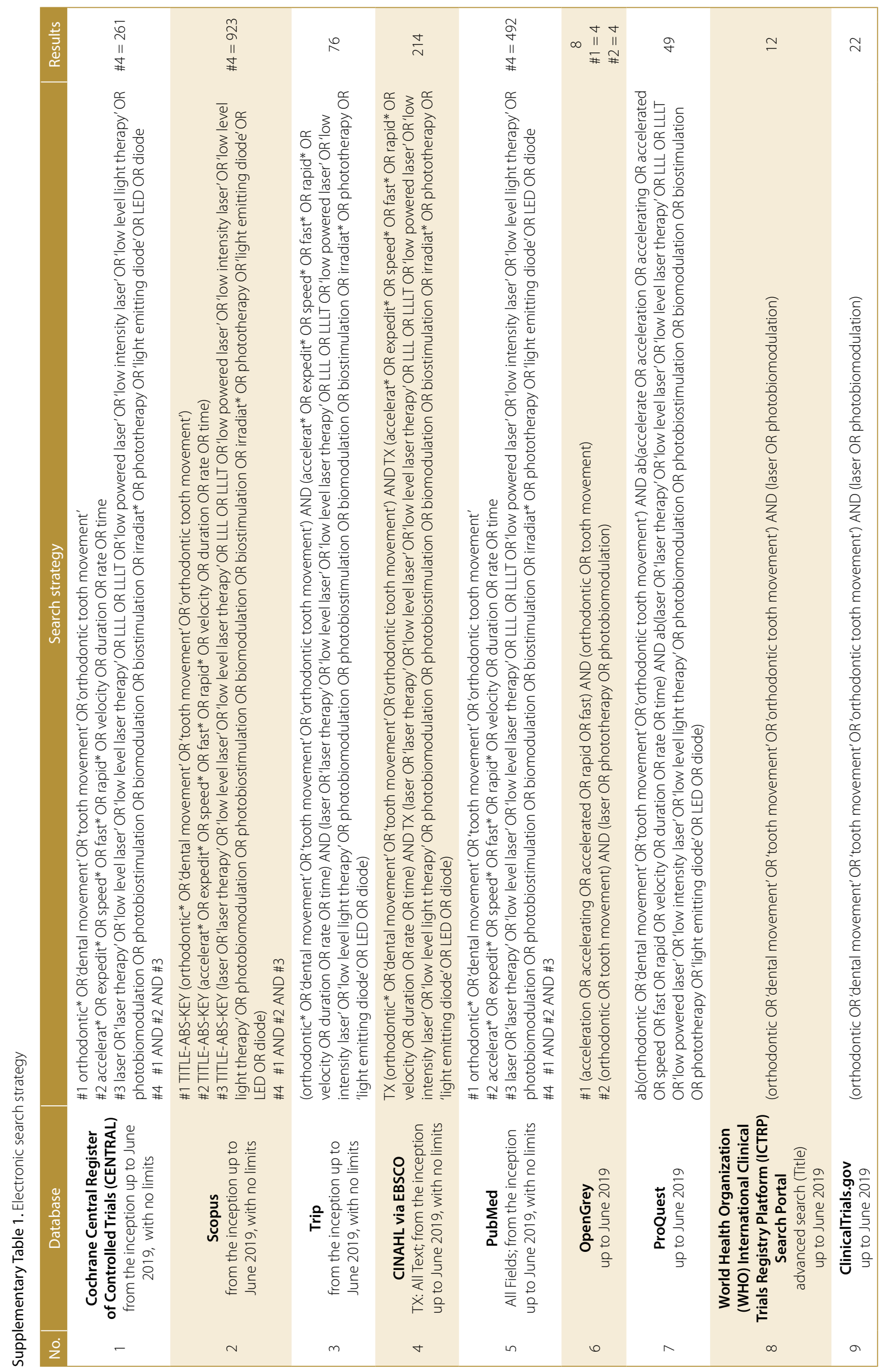


data (attrition bias); selective outcome reporting (reporting bias); and other sources of bias. Then, an overall risk of bias for each trial included was reported according to the following criteria:

- when all fields were assessed as having a low risk of bias, a low risk of bias was reported;

- when 1 or more fields were assessed as having an unclear risk of bias, a moderate risk of bias was reported;

- when 1 or more fields were assessed as being at high risk of bias, a high risk of bias was reported.

The judgments of both reviewers were compared and any disagreements were discussed until a consensus was reached.

\section{Data synthesis}

The data was pooled using the Review Manager (RevMan) v. 5.3 software (the Nordic Cochrane Centre, Copenhagen, Denmark). The inverse variance method with the random effect analysis and mean differences (MDs) with associated $95 \%$ confidence intervals (CIs) were chosen as the analysis methods. The amount of variability among the pooled studies was evaluated by applying the $\chi^{2}$ test and calculating the $I^{2}$ index for heterogeneity. The publication bias was assessed visually using funnel plots for outcomes that were evaluated by 10 trials or more. Finally, the Grading of Recommendations Assessment, Development and Evaluation (GRADE) guidelines were used to rate the overall quality of evidence.

\section{Results}

\section{Literature flow}

A total number of 2,057 references were identified in the electronic search. Duplicates and articles that were beyond the scope of the defined question and PICOS were eliminated. As a result, 57 references were potentially relevant, and were therefore checked in depth. The final results included 25 completed RCTs and 10 ongoing RCTs. Figure 1 shows the detailed search process (PRISMA (Preferred Reporting Items for Systematic Reviews and Meta-Analyses) flow chart). The list of the studies excluded after the full-text assessment, with the reasons for exclusion, is provided in Supplementary Table 2.

\section{Description of the studies}

Twenty-five completed RCTs, including a total of 570 patients, were conducted to investigate the effects of LLLT on the tooth movement. Of the completed studies included, 2 were theses and 3 were reported in a language other than English (2 in Portuguese and 1 in Persian). Different types of tooth movement were described, including leveling and alignment, canine retraction, and en-masse retraction. Table 1 summarizes the characteristics of the completed studies included, whereas Supplementary Table 3 summarizes the characteristics of the ongoing studies.

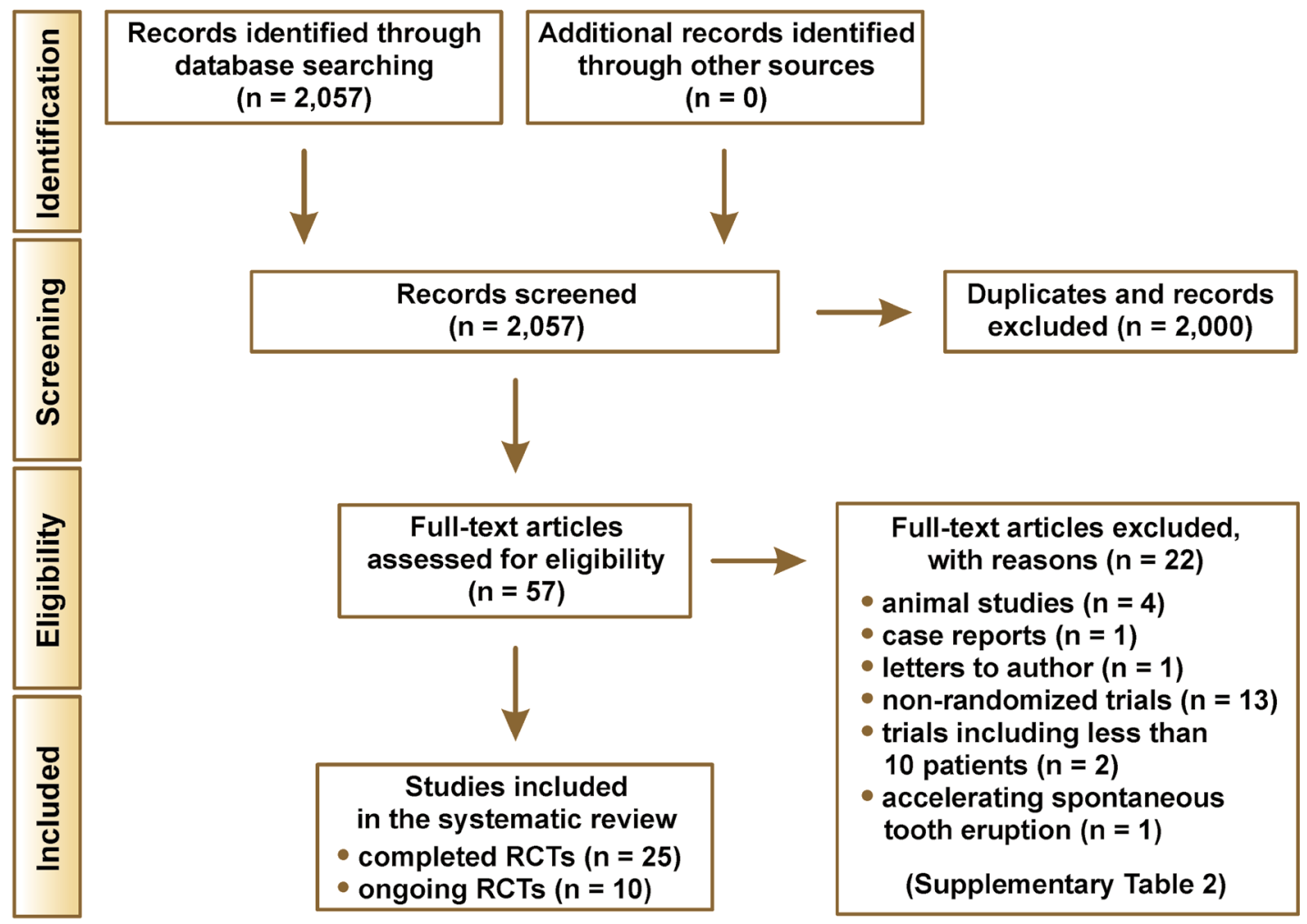

Fig. 1. PRISMA (Preferred Reporting Items for Systematic Reviews and Meta-Analyses) flow chart 
Supplementary Table 2. Studies excluded and the reasons for exclusion

\begin{tabular}{|c|c|c|}
\hline No. & Study & Reason for exclusion \\
\hline 1 & $\begin{array}{l}\text { Genc G, Kocadereli I, Tasar F, Kilinc K, El S, Sarkarati B. Effect of low-level laser therapy (LLLT) on orthodontic tooth movement. } \\
\text { Lasers Med Sci. 2013;28(1):41-47. }\end{array}$ & $\begin{array}{l}\text { non-randomized } \\
\text { controlled trial }\end{array}$ \\
\hline 2 & $\begin{array}{l}\text { Domínguez A, Gómez C, Palma JC. Effects of low-level laser therapy on orthodontics: Rate of tooth movement, pain, } \\
\text { and release of RANKL and OPG in GCF. Lasers Med Sci. 2015;30(2):915-923. }\end{array}$ & $\begin{array}{l}\text { non-randomized } \\
\text { controlled trial }\end{array}$ \\
\hline 3 & $\begin{array}{l}\text { Camacho AD, Cujar SAV. Acceleration effect of orthodontic movement by application of low-intensity laser. J Oral Laser Appl. } \\
\text { 2010;10:99-105. }\end{array}$ & $\begin{array}{l}\text { non-randomized } \\
\text { controlled trial }\end{array}$ \\
\hline 4 & $\begin{array}{l}\text { Youssef M, Ashkar S, Hamade E, Gutknecht N, Lampert F, Mir M. The effect of low-level laser therapy during orthodontic } \\
\text { movement: A preliminary study. Lasers Med Sci. 2008;23(1):27-33. }\end{array}$ & $\begin{array}{l}\text { non-randomized } \\
\text { controlled trial }\end{array}$ \\
\hline 5 & $\begin{array}{l}\text { Xu CW, Zhang ZJ, Zhao J, Cao G. The effect of low energy laser on accelerating orthodontic tooth movement. Med J Qilu. } \\
\text { 2006;1:45-46. }\end{array}$ & $\begin{array}{l}\text { non-randomized } \\
\text { controlled trial }\end{array}$ \\
\hline 6 & $\begin{array}{l}\text { Shaughnessy T, Kantarci A, Kau CH, Skrenes D, Skrenes S, Ma D. Intraoral photobiomodulation-induced orthodontic tooth } \\
\text { alignment: A preliminary study. BMC Oral Health. 2016;16:3. }\end{array}$ & $\begin{array}{l}\text { non-randomized } \\
\text { controlled trial }\end{array}$ \\
\hline 7 & $\begin{array}{l}\text { Gui L, Qu H. Clinical application of low energy laser in acceleration of orthodontic tooth movement. Journal of Dalian Medical } \\
\text { University. 2008;30:155-156. }\end{array}$ & $\begin{array}{l}\text { non-randomized } \\
\text { controlled trial }\end{array}$ \\
\hline 8 & $\begin{array}{l}\text { Kuznetsova M, Zueva SM, Gunenkova IV, Ezhova EE, Ozerova EM. The use of the Optodan laser physiotherapeutic apparatus for } \\
\text { the prevention of complications and the acceleration of the time in treating anomalies in the position of individual teeth with } \\
\text { fixed orthodontic appliances [in Russian]. Stomatologiia (Mosk). 1998;77(3):56-60. }\end{array}$ & $\begin{array}{l}\text { accelerating tooth } \\
\text { eruption }\end{array}$ \\
\hline 9 & $\begin{array}{l}\text { Altan BA, Sokucu O, Toker H, Sumer Z. The effects of low-level laser therapy on orthodontic tooth movement: Metrical and } \\
\text { immunological investigation. JSM Dent. 2014;2(4):1040. }\end{array}$ & $\begin{array}{l}\text { non-randomized } \\
\text { controlled trial }\end{array}$ \\
\hline 10 & $\begin{array}{l}\text { Matarese G, Matarese M, Picciolo G, Fiorillo L, Isola G. Evaluation of low-level laser therapy with diode laser for the } \\
\text { enhancement of the orthodontic tooth movement: A split-mouth study. Preprints. 2018:2018090273. }\end{array}$ & $\begin{array}{l}\text { non-randomized } \\
\text { controlled trial }\end{array}$ \\
\hline 11 & $\begin{array}{l}\text { Monea A, Mo M, Pop D, Bersescu G. The effect of low level laser therapy on orthodontic tooth movement. } \\
\text { J Optoelectron Adv M. 2015;9(1-2):286-289. }\end{array}$ & $\begin{array}{l}\text { non-randomized } \\
\text { controlled trial }\end{array}$ \\
\hline 12 & $\begin{array}{l}\text { Mc Quattie Pimentel IC. The effect of light accelerated therapy for orthodontic tooth movement: A prospective split-mouth } \\
\text { clinical trial. 2017. (Order No. 10259785). Available from ProQuest Dissertations \& Theses Global (1894849499). }\end{array}$ & $\begin{array}{l}\text { only } 5 \text { patients } \\
\text { included }\end{array}$ \\
\hline 13 & $\begin{array}{l}\text { Chung SE, Tompson B, Gong SG. The effect of light emitting diode phototherapy on rate of orthodontic tooth movement: } \\
\text { A split mouth, controlled clinical trial. J Orthod. 2015;42(4):274-283. }\end{array}$ & $\begin{array}{l}\text { less than } 10 \text { patients } \\
\text { included }\end{array}$ \\
\hline 14 & NCT03202355 & $\begin{array}{l}\text { non-randomized } \\
\text { controlled trial }\end{array}$ \\
\hline 15 & ACTRN12610001067066 & $\begin{array}{l}\text { non-randomized } \\
\text { controlled trial }\end{array}$ \\
\hline 16 & $\begin{array}{l}\text { Fernandes MRU, Suzuki SS, Suzuki H, Martinez E, Garcez AS. Photobiomodulation increases intrusion tooth movement and } \\
\text { modulates IL-6, IL-8 and IL-1 } \beta \text { expression during orthodontically bone remodeling. J Biophotonics. 2019;12(10):e201800311. }\end{array}$ & $\begin{array}{l}\text { non-randomized } \\
\text { controlled trial }\end{array}$ \\
\hline 17 & $\begin{array}{l}\text { Isola G, Ferlito S, Rapisarda E. Low-level laser therapy increases interleukin-1 } \beta \text { in gingival crevicular fluid and enhances the rate } \\
\text { of orthodontic tooth movement. Am J Orthod Dentofacial Orthop. 2019;155(4):456-457. }\end{array}$ & letter to author \\
\hline 18 & $\begin{array}{l}\text { Yang H, Liu J, Yang K. Comparative study of } 660 \text { and } 830 \text { nm photobiomodulation in promoting orthodontic tooth movement. } \\
\text { Photobiomodul Photomed Laser Surg. 2019;37(6):349-355. }\end{array}$ & animal study \\
\hline 19 & $\begin{array}{l}\text { Cordeiro JM, Sahad MG, Cavalcanti MFXB, et al. Laser photobiomodulation over teeth subjected to orthodontic movement. } \\
\text { Photomed Laser Surg. 2018;36(12):647-652. }\end{array}$ & animal study \\
\hline 20 & $\begin{array}{l}\text { Ojima K, Dan C, Watanabe H, Kumagai Y. Upper molar distalization with Invisalign treatment accelerated by } \\
\text { photobiomodulation. J Clin Orthod. 2018;52(12):675-683. }\end{array}$ & case report \\
\hline 21 & $\begin{array}{l}\text { Hsu LF, Tsai MH, Shih AH,et al. } 970 \text { nm low-level laser affects bone metabolism in orthodontic tooth movement. } \\
\text { J Photochem Photobiol B. 2018;186:41-50. }\end{array}$ & animal study \\
\hline 22 & $\begin{array}{l}\text { Narmada IB, Rubianto M, Putra ST. The role of low-intensity biostimulation laser therapy in transforming growth factor } \beta 1 \text {, bone alkaline } \\
\text { phosphatase and osteocalcin expression during orthodontic tooth movement in Cavia porcellus. Eur J Dent. 2019;13(1):102-107. }\end{array}$ & animal study \\
\hline
\end{tabular}

\section{Effects of interventions}

The included studies were grouped according to the type of tooth movement achieved and the region of LLLT application (i.e., intra-orally or extra-orally). The vast majority of the included studies used $\mathrm{J} / \mathrm{cm}^{2}$ to express the dosage used. However, the current recommendations of the World Association for photobiomoduLation Therapy (WALT) suggest reporting the low-level laser (LLL) dosage in terms of the total number of joules applied
(J, total energy). Accordingly, we calculated the total number of joules applied per month for each study, using the formula:

$$
\begin{gathered}
\text { total number } \\
\text { of joules }
\end{gathered}=\begin{gathered}
\text { power (total } \\
\text { watts applied })
\end{gathered} \times \begin{gathered}
\text { time (total seconds } \\
\text { of application })
\end{gathered}
$$

per month (Table 1). However, it was unattainable to subcategorize the studies according to the total number of joules applied per month due to a wide variety of doses used. 


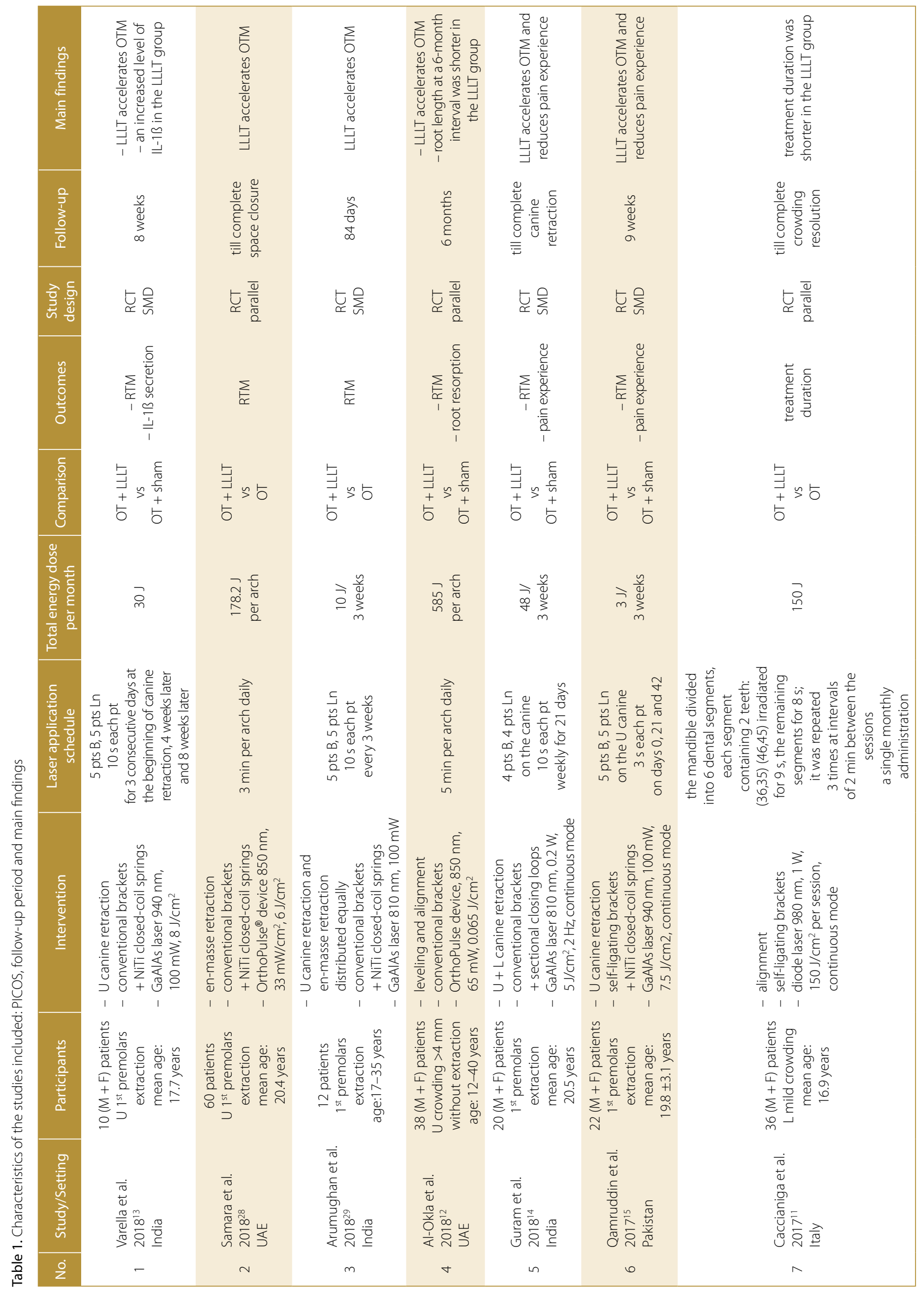




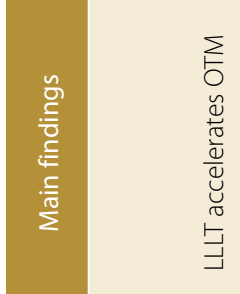

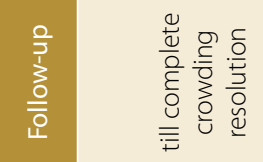

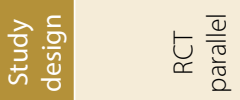

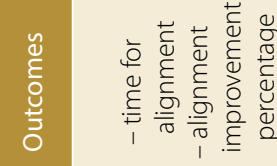

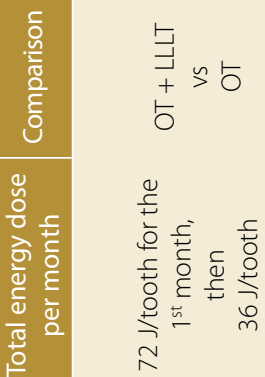

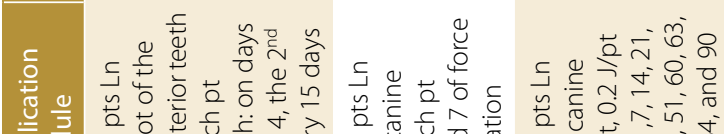

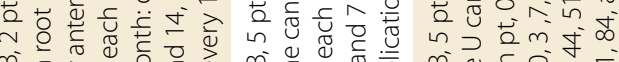
m

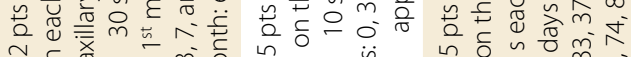

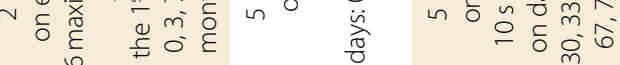

चี

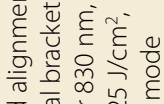

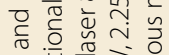

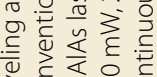

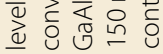

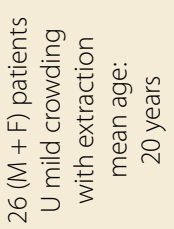

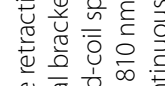

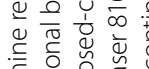

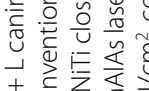

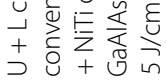

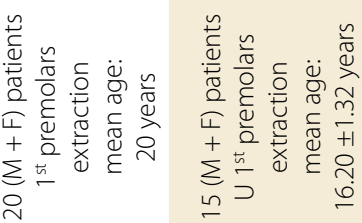

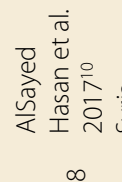

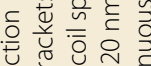

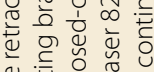

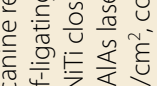

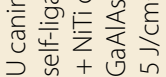

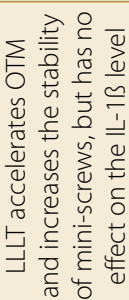

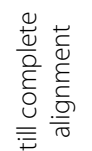

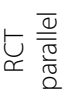

๒

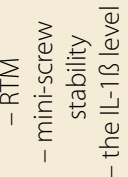

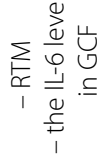

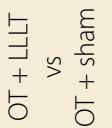

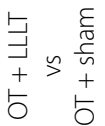

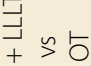

$\stackrel{+}{\circ}$

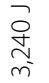

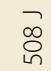

$\stackrel{\infty}{\sim}$

ఫ్

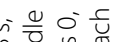

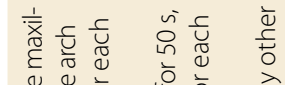

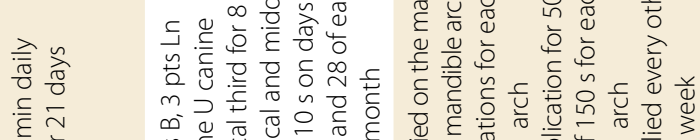
ำ ํํำ

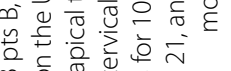
年

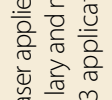

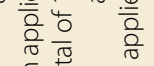

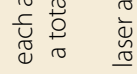

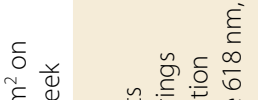
हैँ

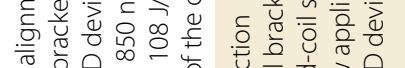

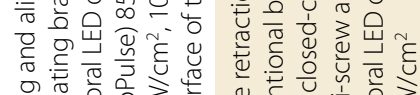

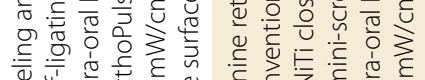

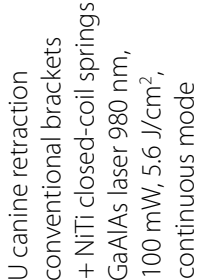
$\xi$ 중 용 ㄴ.

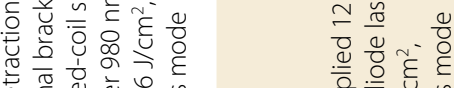

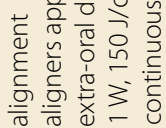
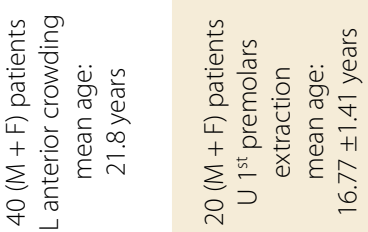

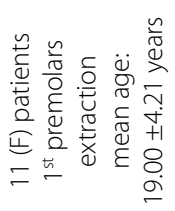
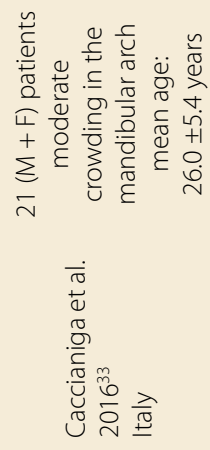

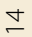




\begin{tabular}{|c|c|c|c|c|c|c|}
\hline & 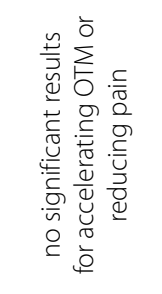 & 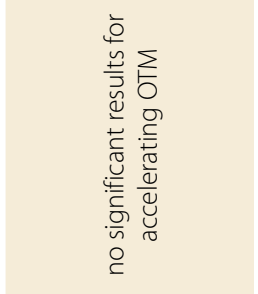 & 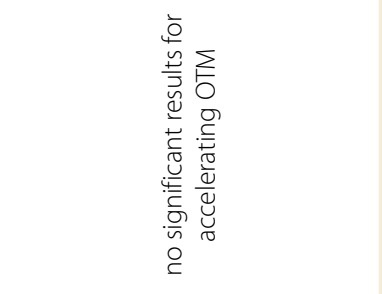 & 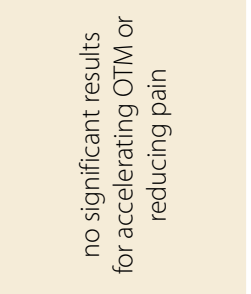 & 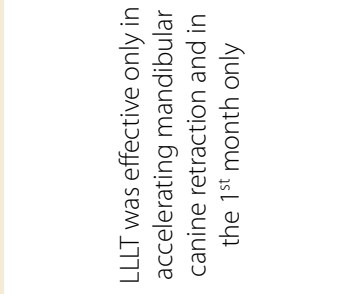 & 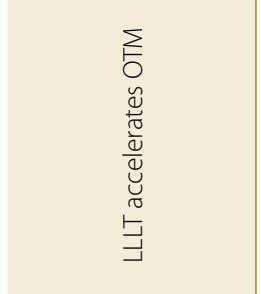 \\
\hline 응 & $\begin{array}{l}\frac{n}{\widehat{0}} \\
\frac{0}{6}\end{array}$ & $\begin{array}{l}\frac{n}{0} \\
\frac{0}{0} \\
0 \\
0\end{array}$ & 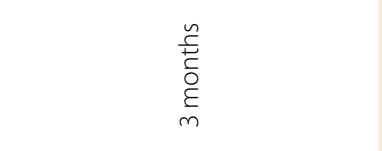 & $\begin{array}{l}\text { ñ } \\
\text { ỗ } \\
0 \\
i n\end{array}$ & 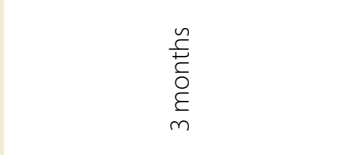 & 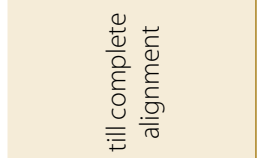 \\
\hline 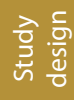 & 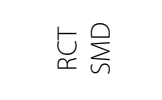 & $\underbrace{}_{\propto} \sum_{n}^{0}$ & $\underset{\propto \Sigma}{t} \sum_{n}^{0}$ & $\underset{\propto \Sigma}{t} \sum_{n}^{0}$ & $\sum_{\propto \infty}^{5}$ & 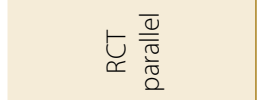 \\
\hline & 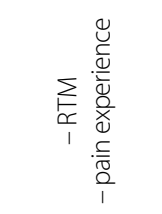 & $\sum_{\infty}$ & 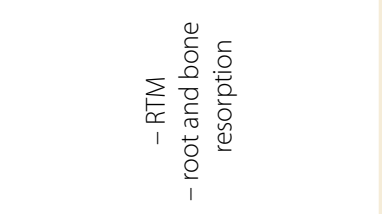 & 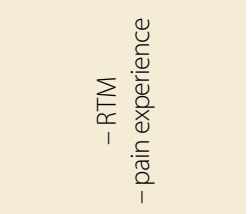 & 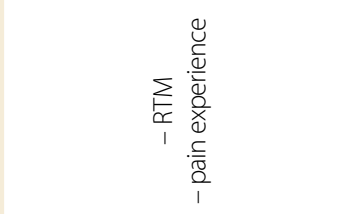 & $\sum_{\substack{\infty \\
\text { s. }}}$ \\
\hline ? & $\begin{array}{l}\stackrel{5}{\exists} \\
\underset{+}{+} \\
5\end{array}$ & $\begin{array}{l}\stackrel{b}{\exists}_{+} \\
\stackrel{5}{5}\end{array}$ & 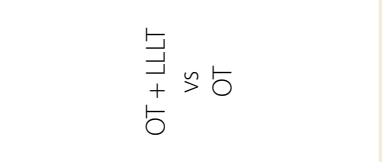 & 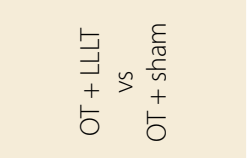 & $\begin{array}{l}\stackrel{\sqcup}{\exists} \\
\begin{array}{c}+ \\
5\end{array} \\
5\end{array}$ & 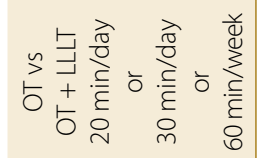 \\
\hline 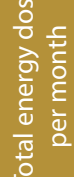 & $*$ & 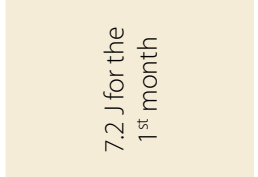 & لَّ & ఫ্ & 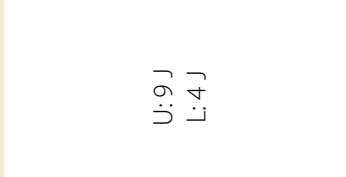 & 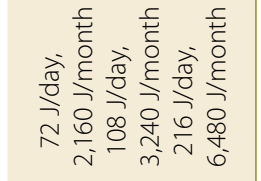 \\
\hline 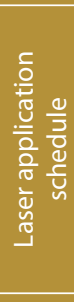 & 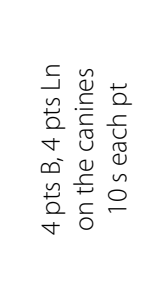 & 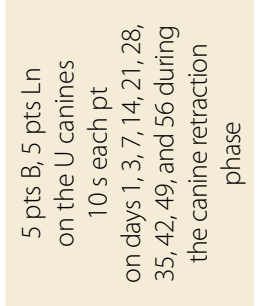 & 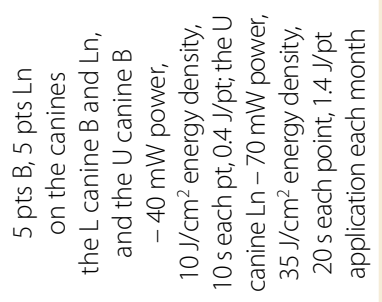 & 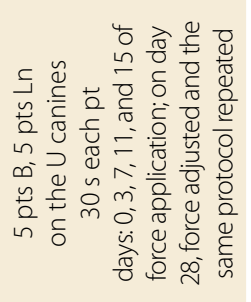 & 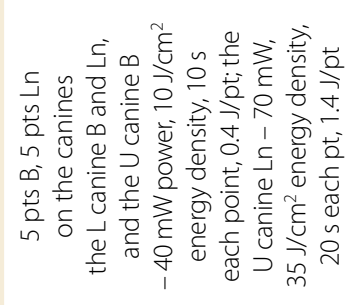 & 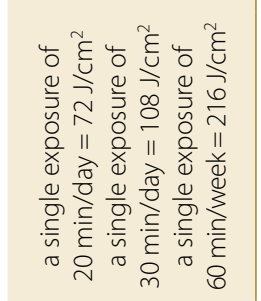 \\
\hline & 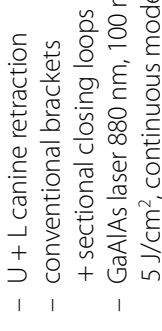 & 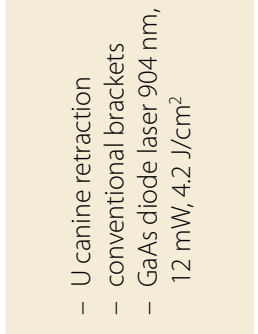 & 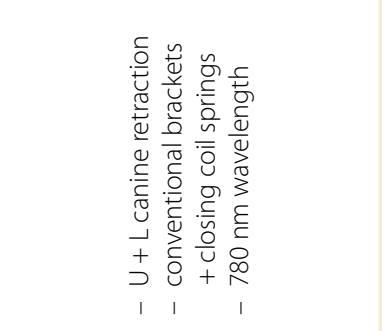 & 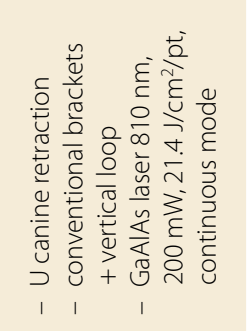 & 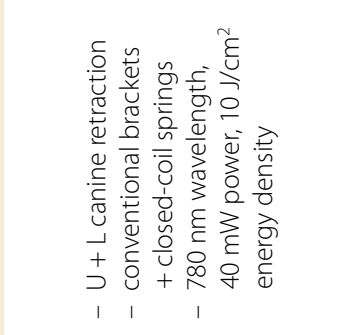 & 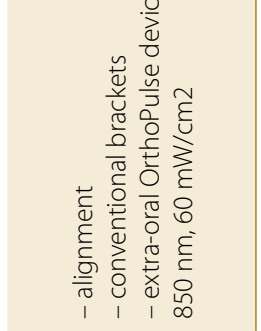 \\
\hline 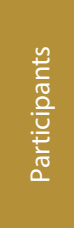 & 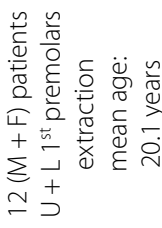 & 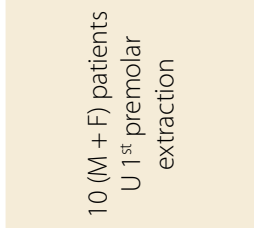 & 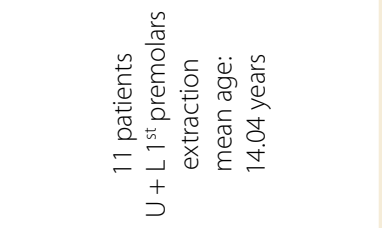 & 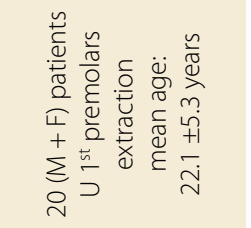 & 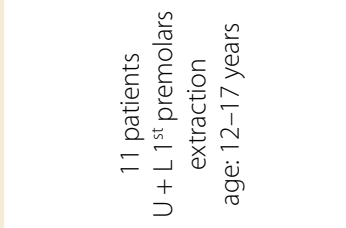 & 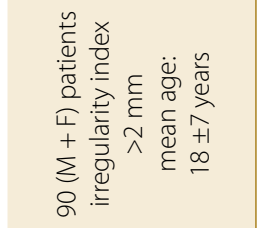 \\
\hline & 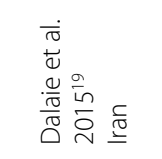 & 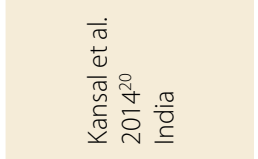 & 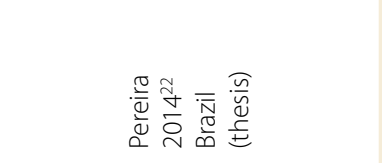 & 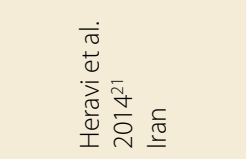 & 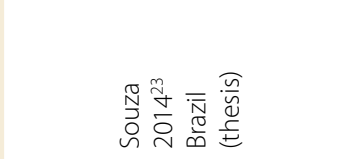 & 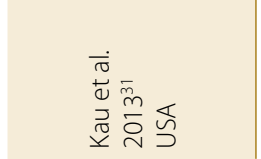 \\
\hline$\frac{c}{4}$ & $\stackrel{\sim}{\sim}$ & $\stackrel{\circ}{\circ}$ & $\approx$ & $\stackrel{\infty}{\simeq}$ & $\stackrel{\tau}{ }$ & $\stackrel{\sim}{ }$ \\
\hline
\end{tabular}




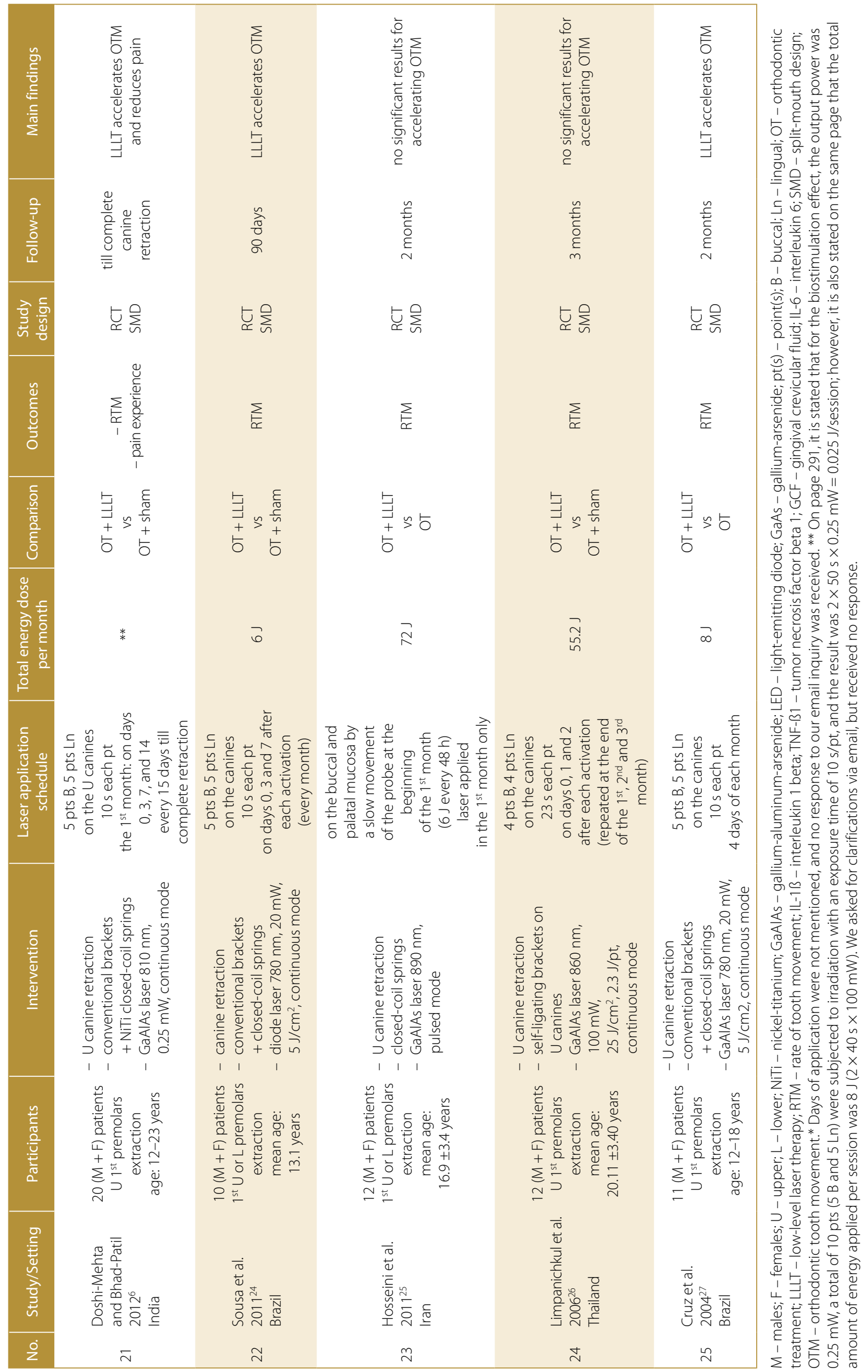


Supplementary Table 3. Characteristics of the ongoing studies on the tooth movement facilitated by low-level-laser therapy (LLLT): Study design and intervention

\begin{tabular}{|c|c|c|c|}
\hline No. & Study/Setting & Study design & Intervention \\
\hline 1 & NCT03646942, 2017, Syria (recruiting) & $\mathrm{RCT}$ & lingual fixed orthodontic appliance \\
\hline 2 & CTRI/2018/05/014328, 2017, India & $\mathrm{RCT}$ & fixed orthodontic appliance \\
\hline 3 & CTRI/2018/04/013156, 2017, India & $\mathrm{RCT}$ & fixed orthodontic appliance \\
\hline 4 & CTRI/2018/03/012316, 2018, India & $\mathrm{RCT}$ & fixed orthodontic appliance \\
\hline 5 & CTRI/2017/07/009153, 2016, India & $\mathrm{RCT}$ & fixed orthodontic appliance \\
\hline 6 & NCT02181439, 2014, France (completed) & $\mathrm{RCT}$ & intermaxillary elastics II \\
\hline 7 & NCT02954133, 2016, USA (active, not recruiting) & $\mathrm{RCT}$ & aligners \\
\hline 8 & NCT02267850, 2014, USA (completed) & $\mathrm{RCT}$ & fixed orthodontic appliance \\
\hline 9 & NCT02267824, 2014, USA (completed) & $\mathrm{RCT}$ & fixed orthodontic appliance \\
\hline 10 & DRKS00014964, 2018, Germany (pending) & $\mathrm{RCT}$ & fixed orthodontic appliance \\
\hline
\end{tabular}

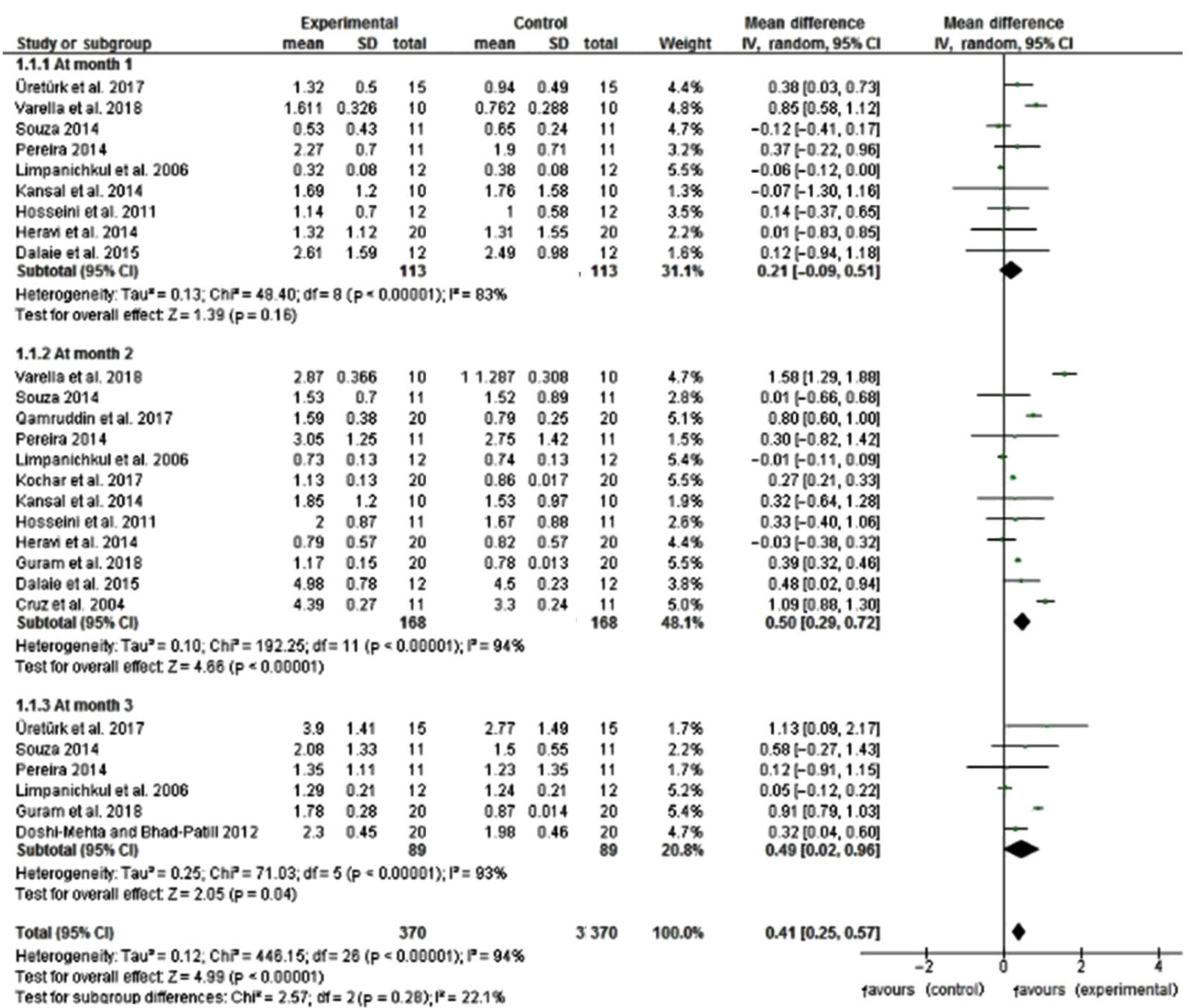

Fig. 2. Forest plot of the comparison between the LLLT and control groups at months 1, 2 and 3 of upper canine retraction

SD - standard deviation; Cl - confidence interval; df - degrees of freedom. 


\section{Effect of intra-oral LLLT in accelerating leveling} and alignment

Three parallel-design RCTs assessed the efficacy of intraoral LLLT in accelerating leveling and alignment, either by assessing the overall treatment time needed for crowding resolution ${ }^{10,11}$ or by assessing the rate of tooth movement. ${ }^{12}$ All 3 studies indicated that LLLT is effective in accelerating the tooth movement. However, the data could not be pooled due to the differences in the treatment scenarios: upper alignment with extraction, lower alignment without extraction and upper alignment without extraction, respectively.

\section{Effect of intra-oral LLLT in accelerating upper canine retraction}

Sixteen split-mouth-design RCTs assessed the efficacy of intra-oral LLLT in accelerating upper canine retraction. ${ }^{6,13-27}$ Noteworthy, the studies by Yassaei et al. and Sousa et al. were not included in data pooling. ${ }^{18,24}$ In Yassaei et al.s study, the analyzed sample comprised fewer than 10 patients due to the early closed extraction spaces at the beginning of the retraction phase. ${ }^{18}$ In the case of the trial by Sousa et al., the data was obtained from a mixture of the upper and lower canines. ${ }^{24}$ Therefore, these 2 studies were omitted to provide an accurate comparison. The amount of retraction at month 1 was assessed by 9 trials, comprising 226 canines. ${ }^{13,17,19-23,25,26}$ The pooled estimate showed no statistically significant differences between the radiated and non-radiated groups (Fig. 2, 1.1.1: WMD (weighted mean difference) $=0.21 ; 95 \% \mathrm{CI}$ $(-0.09,0.51) ; p=0.16)$. Heterogeneity was very significant $\left(\chi^{2}=48.40 ; p<0.001 ; I^{2}=83 \%\right)$. According to GRADE, the overall quality of evidence supporting this outcome is very low (Table 2).

The degree of retraction at month 2 was assessed by 12 trials, comprising 336 canines. ${ }^{13-16,19-23,25-27}$ The pooled estimate showed a greater canine retraction $(0.50 \mathrm{~mm})$ in the radiated group (Fig. 2, 1.1.2: WMD $=0.50 ; 95 \% \mathrm{CI}$ $(0.29,0.72) ; p<0.001)$. Heterogeneity was very significant $\left(\chi^{2}=192.25 ; p<0.001 ; I^{2}=94 \%\right)$. According to GRADE, the overall quality of evidence supporting this outcome is very low (Table 2).

The degree of retraction at month 3 was assessed by 6 trials, comprising 204 canines. . $^{6,14,17,22,23,26}$ The pooled estimate showed a greater canine retraction $(0.49 \mathrm{~mm})$ in the radiated group (Fig. 2, 1.1.3: WMD $=0.49 ; 95 \% \mathrm{CI}(0.02,0.96)$; $p=0.04)$. Heterogeneity was very significant $\left(\chi^{2}=71.03\right.$; $\left.p<0.001 ; I^{2}=93 \%\right)$. According to GRADE, the overall quality of evidence supporting this outcome is low (Table 2).

\section{Effect of intra-oral LLLT in accelerating lower canine retraction}

Five split-mouth-design RCTs assessed this outcome. ${ }^{14,16,19,22,23}$ Three trials including 68 canines assessed the degree of retraction at month $1 .{ }^{19,22,23}$ The pooled estimate showed no significant differences between the radiated

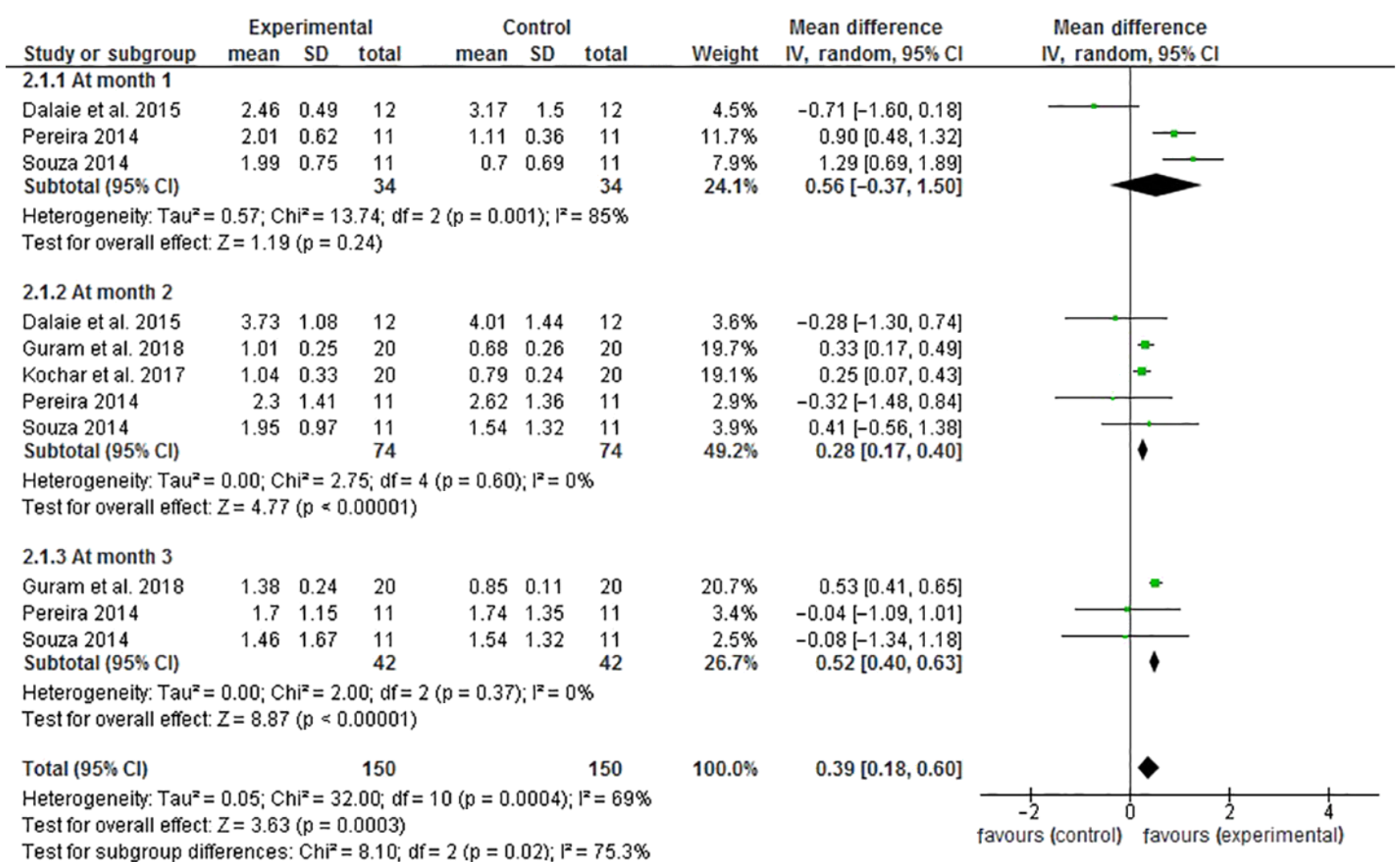

Fig. 3. Forest plot of the comparison between the LLLT and control groups at months 1, 2 and 3 of lower canine retraction 


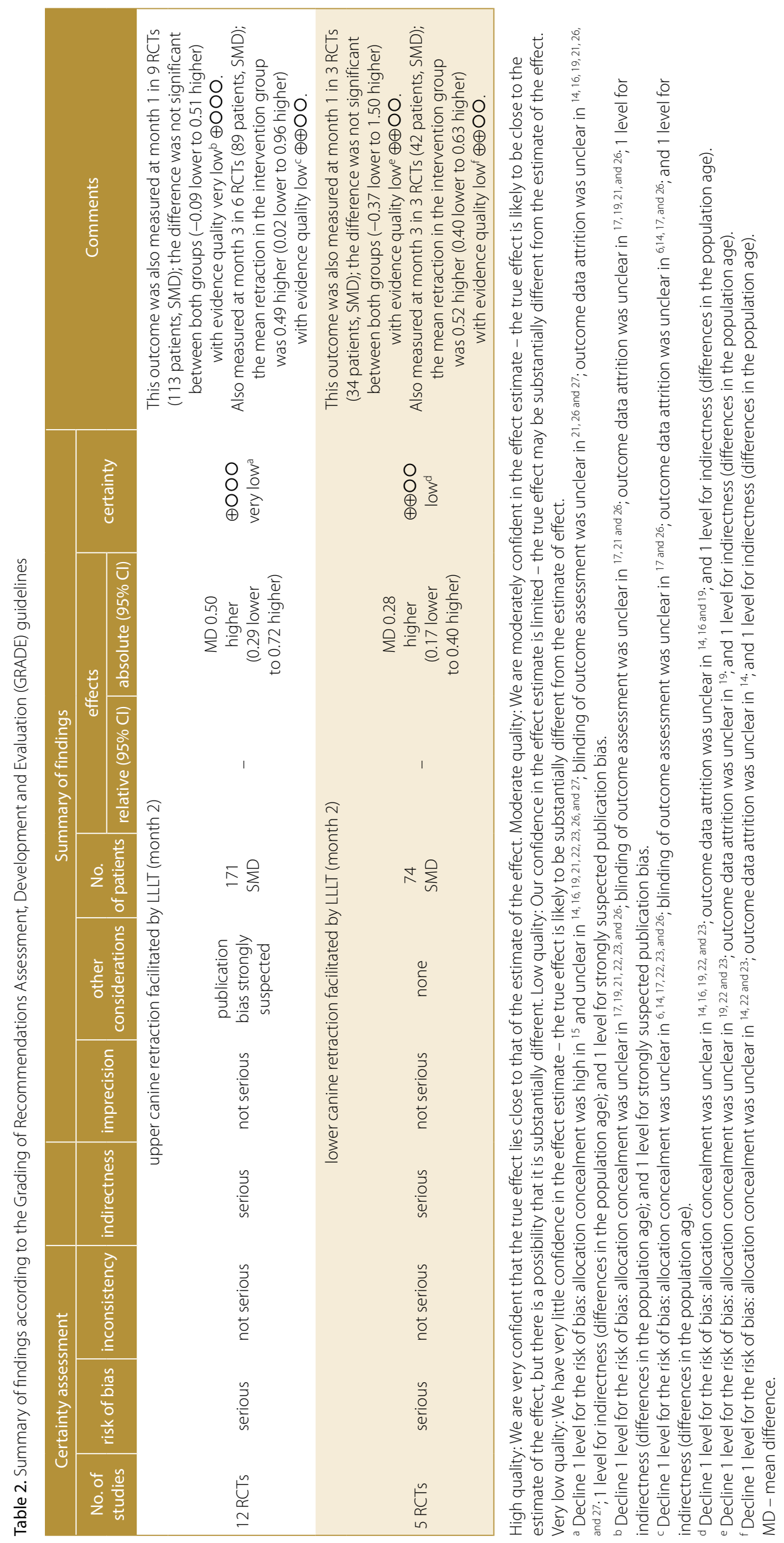


and non-radiated groups after the $1^{\text {st }}$ month of retraction (Fig. 3, 2.1.1: WMD = 0.56; 95\% CI $(-0.37,1.50) ; p=0.24)$. Heterogeneity was very significant $\left(\chi^{2}=13.74 ; p=0.001\right.$; $\left.I^{2}=85 \%\right)$. According to GRADE, the overall quality of evidence supporting this outcome is low (Table 2).

Five trials including 148 canines assessed the degree of retraction at month $2{ }^{14,16,19,22,23}$ The pooled estimate showed a greater tooth movement $(0.28 \mathrm{~mm})$ in the radiated group (Fig. 3, 2.1.2: WMD $=0.28$; 95\% CI $(0.17,0.40)$; $p<0.001)$. Heterogeneity was low $\left(\chi^{2}=2.75 ; p=0.60\right.$; $\left.I^{2}=0 \%\right)$. According to GRADE, the overall quality of evidence supporting this outcome is low (Table 2).

Three trials including 84 canines assessed the degree of retraction at month $3 .{ }^{14,22,23}$ The pooled estimate showed a greater tooth movement $(0.52 \mathrm{~mm})$ in the radiated group (Fig. 3, 2.1.3: WMD $=0.52$; 95\% CI $(0.40,0.63)$; $p<0.001)$. Heterogeneity was low $\left(\chi^{2}=2.00 ; p=0.37\right.$; $\left.I^{2}=0 \%\right)$. According to GRADE, the overall quality of evidence supporting this outcome is low (Table 2).

\section{Effect of intra-oral LLLT in accelerating anterior en-masse retraction}

Two RCTs evaluated this outcome. ${ }^{28,29}$ According to Samara et al., the patients treated with LLLT exhibited a significantly higher velocity of space closure by $0.22 \mathrm{~mm} / \mathrm{month}$ than the non-radiated patients. ${ }^{28}$ According to Arumughan et al., each round of laser application (21 days) accelerated the orthodontic tooth movement by $12.55 \%$ as compared to the conventional retraction technique. ${ }^{29}$ However, the data from the 2 studies could not be pooled, because Arumughan et al's sample consisted of en-masse retraction and canine retraction distributed equally between the experimental and control groups.

\section{Effect of extra-oral LLLT in accelerating leveling and alignment}

Two RCTs assessed the efficacy of extra-oral LLLT in accelerating leveling and alignment. ${ }^{30,31}$ According to Nahas et al., the time was significantly reduced (by 22\%) in the test group as compared to the control group (68.3 vs 87.8 days, respectively; $p<0.043) .{ }^{30}$ According to Kau et al., the mean rates of change in Little's Irregularity Index were 0.49 and $1.12 \mathrm{~mm} /$ week for the control and experimental groups, respectively. ${ }^{31}$ However, the data from the 2 studies could not be pooled, because Nahas et al. used self-ligating brackets, whereas Kau et al. used conventional brackets.

\section{Effect of extra-oral LLLT in accelerating upper canine retraction}

One RCT comprising 40 upper canines from 20 patients assessed the efficacy of extra-oral LLLT in accelerating canine retraction using conventional brackets by evaluating the rate of tooth movement $(\mathrm{mm} /$ day $){ }^{32}$
The results showed a greater tooth movement in the radiated group, by $0.54 \mathrm{~mm}$ in the $1^{\text {st }}$ month, $0.24 \mathrm{~mm}$ in the $2^{\text {nd }}$ month and $0.22 \mathrm{~mm}$ in the $3^{\text {rd }}$ month of retraction.

\section{Effect of extra-oral LLLT in accelerating leveling and alignment using aligners}

One RCT assessed the efficacy of extra-oral LLLT in accelerating leveling and alignment using aligners. ${ }^{33} \mathrm{Cac}$ cianiga et al. allocated 21 patients to either the radiation group or the control group. All the patients were instructed to wear each aligner for $12 \mathrm{~h}$ per day for 2 weeks. In the control group, this 12 -h protocol failed and was replaced by wearing aligners for $22 \mathrm{~h}$ per day. On the other hand, the 12-hour protocol was suitable for the radiated group, meaning the patients had to wear aligners for fewer hours when laser was applied.

\section{Risk of bias in the included studies}

Our analysis found that 4 studies were at low risk of bias, 17 studies were at moderate risk of bias and 4 studies were at high risk of bias. The principle risk factor affecting the methodology of laser studies was incomplete outcome data (attrition bias): $8 \%$ were at high risk of attrition bias, with more than $20 \%$ of the total sample size missing, and $48 \%$ were at unclear risk of bias. Figures 4 and 5 show the summary and graph of the risk of bias of the studies. More details on the assessment of the risk of bias with the supporting reasons for each assessment can be found in Supplementary Table 4.

\section{Publication bias}

The publication bias was assessed visually using standard funnel plots for the outcomes evaluated by 10 studies or more (i.e., the $1^{\text {st }}$ and $2^{\text {nd }}$ month of upper canine retraction). Figure 6 shows the funnel plots of the effect estimate against standard error $(S E)$ for the outcomes. The shapes of the 2 funnel plots were deemed to be asymmetrical, which revealed the existence of the publication bias.

\section{Discussion}

The present systematic review comprised 570 patients from 25 completed RCTs, which reflects the interests of orthodontists in utilizing LLLT for accelerating tooth movement.

The pooled results of canine retraction facilitated by intra-oral LLLT showed no differences in the tooth movement at end of the $1^{\text {st }}$ month, but significant differences after the $2^{\text {nd }}$ and $3^{\text {rd }}$ month. Since radiation has a cumulative effect, it seems that a 1-month period might be needed to achieve the biostimulation effects necessary to stimulate acceleration. 
Supplementary Table 4. Assessment of the risk of bias with the supporting reasons for each assessment

\begin{tabular}{|c|c|c|c|c|}
\hline No. & Study/Setting & Selection bias (randomization) & Selection bias (allocation concealment) & Performance bias \\
\hline 1 & $\begin{array}{l}\text { Varella et al. } \\
2018 \\
\text { India }\end{array}$ & $\begin{array}{l}\text { Low Risk } \\
\text { "The experimental side was assigned by } \\
\text { means of a lottery method with a sealed } \\
\text { envelope." }\end{array}$ & $\begin{array}{l}\text { Low Risk } \\
\text { "The experimental side was assigned by } \\
\text { means of a lottery method with a sealed } \\
\text { envelope." }\end{array}$ & $\begin{array}{l}\text { Low Risk } \\
\text { The participants only were blinded } \\
\text { (it was confirmed by contacting the } \\
\text { corresponding author). According to } \\
\text { the criteria of judging the risk of bias, a } \\
\text { low risk of bias is considered when the } \\
\text { outcome is unlikely to be influenced by a } \\
\text { lack of blinding. }\end{array}$ \\
\hline 2 & $\begin{array}{l}\text { Samara et al. } \\
2018 \\
\text { UAE }\end{array}$ & $\begin{array}{l}\text { Low Risk } \\
\text { "Randomization and allocation } \\
\text { concealment to the patient were achieved } \\
\text { by asking each patient to draw a sealed } \\
\text { envelope containing the allocation." }\end{array}$ & $\begin{array}{c}\text { Low Risk } \\
\text { "Randomization and allocation } \\
\text { concealment to the patient were } \\
\text { achieved by asking each patient to } \\
\text { draw a sealed envelope containing the } \\
\text { allocation." }\end{array}$ & $\begin{array}{l}\text { Low Risk } \\
\text { "It was not possible to conceal the } \\
\text { treatment from both the patients and } \\
\text { clinicians." However, according to the } \\
\text { criteria of judging the risk of bias, a } \\
\text { low risk of bias is considered when the } \\
\text { outcome is unlikely to be influenced by a } \\
\text { lack of blinding. }\end{array}$ \\
\hline 3 & $\begin{array}{l}\text { Arumughan et al. } \\
2018 \\
\text { India }\end{array}$ & $\begin{array}{l}\text { Low Risk } \\
\text { "The experimental side and the control side } \\
\text { were randomly selected by an individual } \\
\text { who was not part of the study."The method } \\
\text { of randomization was not mentioned } \\
\text { in the paper. An email was sent to the } \\
\text { corresponding author, but there was no } \\
\text { response. }\end{array}$ & $\begin{array}{c}\text { Unclear Risk } \\
\text { Concealment was not described in } \\
\text { the article. An email was sent to the } \\
\text { corresponding author, but there was no } \\
\text { response. }\end{array}$ & $\begin{array}{l}\text { Low Risk } \\
\text { The study did not address this outcome. } \\
\text { However, according to the criteria of } \\
\text { judging the risk of bias, a low risk of bias is } \\
\text { considered when the outcome is unlikely } \\
\text { to be influenced by a lack of blinding. }\end{array}$ \\
\hline 4 & $\begin{array}{l}\text { Al-Okla et al. } \\
2018 \\
\text { UAE }\end{array}$ & $\begin{array}{l}\text { Low Risk } \\
\text { "The subjects were randomly divided into } 2 \\
\text { groups."The method of randomization was } \\
\text { not mentioned in the paper. An email was } \\
\text { sent to the corresponding author, but there } \\
\text { was no response. }\end{array}$ & $\begin{array}{l}\text { Unclear Risk } \\
\text { Concealment was not described in } \\
\text { the article. An email was sent to the } \\
\text { corresponding author, but there was no } \\
\text { response. }\end{array}$ & $\begin{array}{l}\text { Low Risk } \\
\text { It was a double-blind clinical trial. } \\
\text { Moreover, according to the criteria of } \\
\text { judging the risk of bias, a low risk of bias is } \\
\text { considered when the outcome is unlikely } \\
\text { to be influenced by a lack of blinding. }\end{array}$ \\
\hline 5 & $\begin{array}{l}\text { Guram et al. } \\
2018 \\
\text { India }\end{array}$ & $\begin{array}{l}\text { Low Risk } \\
\text { "The } 4 \text { quadrants were randomly divided } \\
\text { into the laser and control groups."The } \\
\text { method of randomization was not } \\
\text { mentioned in the paper. An email was sent } \\
\text { to the corresponding author, but there was } \\
\text { no response. }\end{array}$ & $\begin{array}{l}\text { Unclear Risk } \\
\text { Concealment was not described in } \\
\text { the article. An email was sent to the } \\
\text { corresponding author, but there was no } \\
\text { response. }\end{array}$ & $\begin{array}{l}\text { Low Risk } \\
\text { "Neither the participant nor the } \\
1^{\text {st }} \text { evaluator knows the grouping." } \\
\text { Moreover, according to the criteria of } \\
\text { judging the of bias, a low risk of bias is } \\
\text { considered when the outcome is unlikely } \\
\text { to be influenced by a lack of blinding. }\end{array}$ \\
\hline 6 & $\begin{array}{l}\text { Qamruddin et al. } \\
2017 \\
\text { Pakistan }\end{array}$ & $\begin{array}{l}\text { Low Risk } \\
\text { "The maxillary arch was divided into the } \\
\text { experimental and placebo groups by } \\
\text { flipping a coin." }\end{array}$ & $\begin{array}{l}\text { High Risk } \\
\text { It was confirmed by an email, since the } \\
\text { author stated that there was no allocation } \\
\text { concealment. }\end{array}$ & $\begin{array}{l}\text { Low Risk } \\
\text { Although the participants only were } \\
\text { blinded, according to the criteria of } \\
\text { judging the risk of bias, a low risk of bias is } \\
\text { considered when the outcome is unlikely } \\
\text { to be influenced by a lack of blinding. }\end{array}$ \\
\hline 7 & $\begin{array}{l}\text { Caccianiga et al. } \\
2017 \\
\text { Italy }\end{array}$ & $\begin{array}{l}\text { Low Risk } \\
\text { "The subjects were randomly allocated to } \\
\text { receive orthodontic treatment with a fixed } \\
\text { appliance plus the administration of LLLT." } \\
\text { The SPSS Statistics software was used to } \\
\text { generate an allocation sequence. }\end{array}$ & $\begin{array}{l}\text { Low Risk } \\
\text { "Each subject was assigned a study } \\
\text { number that was concealed until the date } \\
\text { of bonding a fixed appliance." }\end{array}$ & $\begin{array}{l}\text { Low Risk } \\
\text { The study did not address this outcome. } \\
\text { However, according to the criteria of } \\
\text { judging the risk of bias, a low risk of bias is } \\
\text { considered when the outcome is unlikely } \\
\text { to be influenced by a lack of blinding. }\end{array}$ \\
\hline 8 & $\begin{array}{l}\text { AlSayed } \\
\text { Hasan et al. } \\
2017 \\
\text { Syria }\end{array}$ & $\begin{array}{l}\text { Low Risk } \\
\text { A simple randomization technique was } \\
\text { used. "Each patient was asked to select } \\
\text { a folded piece of paper from a box } \\
\text { containing } 26 \text { pieces of paper." }\end{array}$ & $\begin{array}{l}\text { Low Risk } \\
\text { Allocation concealment was done } \\
\text { (it was confirmed by contacting the } \\
\text { corresponding author). }\end{array}$ & $\begin{array}{l}\text { Low Risk } \\
\text { Although there was no blinding, } \\
\text { according to the criteria of judging the } \\
\text { risk of bias, a low risk of bias is considered } \\
\text { when the outcome is unlikely to be } \\
\text { influenced by a lack of blinding. }\end{array}$ \\
\hline 9 & $\begin{array}{l}\text { Kochar et al. } \\
2017 \\
\text { India }\end{array}$ & $\begin{array}{l}\text { Low Risk } \\
\text { "The randomly selected split-mouth design } \\
\text { was used." } \\
\text { The method of randomization was not } \\
\text { described in the paper. An email was sent } \\
\text { to the corresponding author, but there was } \\
\text { no response. }\end{array}$ & $\begin{array}{c}\text { Unclear Risk } \\
\text { Concealment was not described in } \\
\text { the article. An email was sent to the } \\
\text { corresponding author, but there was no } \\
\text { response. }\end{array}$ & $\begin{array}{l}\text { Low Risk } \\
\text { Although the participants only were } \\
\text { blinded, according to the criteria of } \\
\text { judging the risk of bias, a low risk of bias is } \\
\text { considered when the outcome is unlikely } \\
\text { to be influenced by a lack of blinding. }\end{array}$ \\
\hline
\end{tabular}


Low Risk

The outcome assessor was blinded (it was confirmed by contacting the corresponding author).
Low Risk

"The study models were pooled and coded. All measurements were obtained by a single investigator who was blinded to the group allocation of the study models."
Low Risk

No dropouts, as mentioned in the corresponding author's email.
Low Risk

All the outcomes defined in Low Risk the methods section were None. measured and reported.

\section{High Risk}

More than 20\% (25\%) of the sample were dropped. Moreover, the missing data was not balanced in the numbers and reasons across the groups.
Low Risk

Low Risk

All the outcomes defined in the methods section were measured and reported.
"The photobiomodulation devices were provided by Biolux Research, which had no role in

the design or execution of this study."

\section{Unclear Risk}

The study did not address this outcome. An email was sent to the corresponding author, but there was no response. It is mentioned that the distance was measured 3 times, and the mean value is used for the data.

\section{Unclear Risk}

The study did not address this outcome. An email was sent to the corresponding author, but there was no response.
Unclear Risk

The study did not address this outcome. An email was sent to the corresponding author, but there was no response.

\section{High Risk}

More than 20\% (31\%) of the sample were dropped. Moreover, the missing data was not balanced in the numbers across the groups.

\section{Low Risk}

All the outcomes defined in the methods section were measured and reported.
Low Risk None.
Unclear Risk

Low Risk

The outcome was instrumentally measured and rechecked by another investigator for verification.

\section{Low Risk}

It was confirmed by an email, since the author stated that the outcome was instrumentally measured and rechecked by other assessors without any knowledge of the grouping.

\section{Low Risk}

The study did not address this outcome. An email was sent to the corresponding author, but there was no response.
Low Risk

All the outcomes defined in the methods section were measured and reported.
Low Risk

"This study was self-funded by the authors and their institution."
The missing outcome data was less than 20\% (18\%). Moreover, the missing data was balanced in the numbers, with similar reasons for the missing data across the groups.
Low Risk

All the outcomes defined in Low Risk

the methods section were None.
Low Risk

All the outcomes defined in Low Risk

the methods section were None. measured and reported.

\section{Unclear Risk}

The study did not address this outcome. An email was sent to the corresponding author, but there was no

$$
\text { response. }
$$

\section{Low Risk}

As illustrated on the CONSORT flow chart, there was no missing data.

\section{High Risk}

The outcome assessor was not blinded (it was confirmed by contacting the corresponding author)
Low Risk

As illustrated on the CONSORT flow chart, there was no missing data.
Low Risk

All the outcomes defined in Low Risk

the methods section were None. measured and reported.
Low Risk

All the outcomes defined in Low Risk the methods section were None.
Low Risk

"All measurements were recorded by the same person. He/she was blinded to the control and lased sides."
Unclear Risk

The study did not address this outcome. An email was sent to the corresponding author, but there was no response.
Low Risk

All the outcomes defined in Low Risk

the methods section were None. measured and reported. 


\begin{tabular}{|c|c|c|c|c|}
\hline No. & Study/Setting & Selection bias (randomization) & Selection bias (allocation concealment) & Performance bias \\
\hline 10 & $\begin{array}{l}\text { Üretürk et al. } \\
2017 \\
\text { Turkey }\end{array}$ & $\begin{array}{l}\text { Low Risk } \\
\text { "The canines were randomly separated } \\
\text { into } 2 \text { groups consisting of } 30 \text { teeth." } \\
\text { The method of randomization was not } \\
\text { described in the paper. An email was sent } \\
\text { to the corresponding author, but there was } \\
\text { no response. }\end{array}$ & $\begin{array}{l}\text { Unclear Risk } \\
\text { Concealment was not described in } \\
\text { the article. An email was sent to the } \\
\text { corresponding author, but there was no } \\
\text { response. }\end{array}$ & $\begin{array}{l}\text { Low Risk } \\
\text { The study did not address this outcome. } \\
\text { However, according to the criteria of } \\
\text { judging the risk of bias, a low risk of bias is } \\
\text { considered when the outcome is unlikely } \\
\text { to be influenced by a lack of blinding. }\end{array}$ \\
\hline 11 & $\begin{array}{l}\text { Nahas et al. } \\
2016 \\
\text { UAE }\end{array}$ & $\begin{array}{l}\text { Low Risk } \\
\text { "The patients were randomly assigned } \\
\text { to one of the } 2 \text { groups utilizing simple } \\
\text { randomization by asking them to draw a } \\
\text { sealed envelope." }\end{array}$ & $\begin{array}{l}\text { Low Risk } \\
\text { They used a sealed envelope to conceal } \\
\text { allocation. }\end{array}$ & $\begin{array}{l}\text { Low Risk } \\
\text { Although there was no blinding, } \\
\text { according to the criteria of judging the } \\
\text { risk of bias, a low risk of bias is considered } \\
\text { when the outcome is unlikely to be } \\
\text { influenced by a lack of blinding. }\end{array}$ \\
\hline 12 & $\begin{array}{l}\text { Ekizer et al. } \\
2016 \\
\text { Turkey }\end{array}$ & $\begin{array}{l}\text { Low Risk } \\
\text { "Randomization was accomplished with } \\
\text { random LPT application side selection by } \\
\text { coin tossing." }\end{array}$ & $\begin{array}{l}\text { Low Risk } \\
\text { "The treatment allocation was concealed } \\
\text { in envelopes labeled with the study } \\
\text { identification number." }\end{array}$ & $\begin{array}{l}\text { Low Risk } \\
\text { Although the participants only were } \\
\text { blinded, according to the criteria of } \\
\text { judging the risk of bias, a low risk of bias is } \\
\text { considered when the outcome is unlikely } \\
\text { to be influenced by a lack of blinding. }\end{array}$ \\
\hline 13 & $\begin{array}{l}\text { Yassaei et al. } \\
2016 \\
\text { Iran }\end{array}$ & $\begin{array}{l}\text { Low Risk } \\
\text { "All irradiations were performed by } \\
1 \text { operator in } 1 \text { maxillary quadrant which } \\
\text { was randomly selected."The method } \\
\text { of randomization was not described } \\
\text { in the paper. An email was sent to the } \\
\text { corresponding author, but there was no } \\
\text { response. }\end{array}$ & $\begin{array}{l}\text { Unclear Risk } \\
\text { The study did not address this outcome. } \\
\text { An email was sent to the corresponding } \\
\text { author, but there was no response. }\end{array}$ & $\begin{array}{l}\text { Low Risk } \\
\text { The participants and the clinicians } \\
\text { responsible for the treatment stages } \\
\text { were blinded. Moreover, according to } \\
\text { the criteria of judging the risk of bias, } \\
\text { a low risk of bias is considered when the } \\
\text { outcome is unlikely to be influenced by } \\
\text { a lack of blinding. }\end{array}$ \\
\hline 14 & $\begin{array}{l}\text { Caccianiga et al. } \\
2016 \\
\text { Italy }\end{array}$ & $\begin{array}{l}\text { Low Risk } \\
\text { "The block randomization method was } \\
\text { used. Each block contained } 4 \text { patients." }\end{array}$ & $\begin{array}{l}\text { Unclear Risk } \\
\text { The study did not address this outcome. } \\
\text { An email was sent to the corresponding } \\
\text { author, but there was no response. }\end{array}$ & $\begin{array}{l}\text { Low Risk } \\
\text { Although there was no blinding, } \\
\text { according to the criteria of judging risk of } \\
\text { bias, a low risk of bias is considered when } \\
\text { the outcome is unlikely to be influenced } \\
\text { by a lack of blinding. }\end{array}$ \\
\hline 15 & $\begin{array}{l}\text { Dalaie et al. } \\
2015 \\
\text { Iran }\end{array}$ & $\begin{array}{l}\text { Low Risk } \\
\text { "The } 4 \text { quadrants were randomly selected } \\
\text { in a complete block randomization manner } \\
\text { using the Microsoft Excel software." }\end{array}$ & $\begin{array}{l}\text { Unclear Risk } \\
\text { The study did not address this outcome. } \\
\text { An email was sent to the corresponding } \\
\text { author, but there was no response. }\end{array}$ & $\begin{array}{l}\text { Low Risk } \\
\text { Although the participants only were } \\
\text { blinded, according to the criteria of } \\
\text { judging the risk of bias, a low risk of bias is } \\
\text { considered when the outcome is unlikely } \\
\text { to be influenced by a lack of blinding. }\end{array}$ \\
\hline 16 & $\begin{array}{l}\text { Kansal et al. } \\
2014 \\
\text { India }\end{array}$ & $\begin{array}{l}\text { Low Risk } \\
\text { "The right and left quadrants were assigned } \\
\text { to either of the groups randomly at a coin } \\
\text { toss to eliminate the left and right side bias, } \\
\text { if any." }\end{array}$ & $\begin{array}{l}\text { Low Risk } \\
\text { "Random selection was done by } \\
1 \text { operator, who conveyed to the person } \\
\text { doing the laser application as to which } \\
\text { quadrant of the patient belongs to the } \\
\text { laser group." }\end{array}$ & $\begin{array}{l}\text { Low Risk } \\
\text { According to the criteria of judging the } \\
\text { risk of bias, a low risk of bias is considered } \\
\text { when the outcome is unlikely to be } \\
\text { influenced by a lack of blinding. }\end{array}$ \\
\hline 17 & $\begin{array}{l}\text { Pereira } \\
2014 \\
\text { Brazil } \\
\text { (thesis) }\end{array}$ & $\begin{array}{l}\text { Low Risk } \\
\text { Laser was applied randomly only in } 1 \text { of } \\
\text { the canines in the maxilla and in } 1 \text { of the } \\
\text { canines in the mandible. }\end{array}$ & $\begin{array}{l}\text { Unclear Risk } \\
\text { The study did not address this outcome. }\end{array}$ & $\begin{array}{l}\text { Low Risk } \\
\text { According to the criteria of judging the } \\
\text { risk of bias, a low risk of bias is considered } \\
\text { when the outcome is unlikely to be } \\
\text { influenced by a lack of blinding. }\end{array}$ \\
\hline 18 & $\begin{array}{l}\text { Heravi et al. } \\
2014 \\
\text { Iran }\end{array}$ & $\begin{array}{l}\text { Low Risk } \\
\text { "In each patient, one side was randomly } \\
\text { allocated to laser treatment and another } \\
\text { side to the placebo application."The } \\
\text { method of randomization was not } \\
\text { described in the paper. An email was sent } \\
\text { to the corresponding author, but there was } \\
\text { no response. }\end{array}$ & $\begin{array}{l}\text { Unclear Risk } \\
\text { The study did not address this outcome. } \\
\text { An email was sent to the corresponding } \\
\text { author, but there was no response. }\end{array}$ & $\begin{array}{l}\text { Low Risk } \\
\text { Although the participants only were } \\
\text { blinded, according to the criteria of } \\
\text { judging the risk of bias, a low risk of bias is } \\
\text { considered when the outcome is unlikely } \\
\text { to be influenced by a lack of blinding. }\end{array}$ \\
\hline
\end{tabular}




\begin{tabular}{|c|c|c|c|}
\hline Detection bias & Attrition bias & Reporting bias & Other bias \\
\hline $\begin{array}{l}\text { Unclear Risk } \\
\text { The study did not address this outcome. An email } \\
\text { was sent to the corresponding author, but there } \\
\text { was no response. Noteworthy, the movements were } \\
\text { measured using the Ortho AnalyzerTM software, } \\
\text { whereas the reference points were selected manually. }\end{array}$ & $\begin{array}{l}\text { Unclear Risk } \\
\text { The study did not address this } \\
\text { outcome. An email was sent } \\
\text { to the corresponding author, } \\
\text { but there was no response. }\end{array}$ & $\begin{array}{l}\text { Low Risk } \\
\text { All the outcomes defined in } \\
\text { the methods section were } \\
\text { measured and reported. }\end{array}$ & $\begin{array}{c}\text { Low Risk } \\
\text { None. }\end{array}$ \\
\hline $\begin{array}{l}\text { Low Risk } \\
\text { "The alignment of the } 6 \text { lower anterior teeth was } \\
\text { evaluated by a single investigator who was blinded } \\
\text { regarding the patients'group allocation." }\end{array}$ & $\begin{array}{l}\text { Unclear Risk } \\
\text { Although the missing data was } \\
\text { less than } 20 \% \text { (15\%), it was not } \\
\text { equally distributed between } \\
\text { the } 2 \text { groups. Furthermore, the } \\
\text { reasons for dropping out were } \\
\text { different. }\end{array}$ & $\begin{array}{l}\text { Low Risk } \\
\text { All the outcomes defined in } \\
\text { the methods section were } \\
\text { measured and reported. }\end{array}$ & $\begin{array}{l}\text { Low Risk } \\
\text { It is mentioned that the } \\
\text { devices were provided by } \\
\text { Biolux Research and American } \\
\text { Orthodontics. None of the } \\
\text { sponsors (listed companies) } \\
\text { had any role in the design or } \\
\text { execution of this study. }\end{array}$ \\
\hline $\begin{array}{l}\text { Low Risk } \\
\text { "The measurements of the data were done by } \\
\text { a clinician blinded to the assignment." }\end{array}$ & $\begin{array}{l}\text { Low Risk } \\
\text { As illustrated on the CONSORT } \\
\text { flow chart, there was no } \\
\text { missing data. }\end{array}$ & $\begin{array}{l}\text { Low Risk } \\
\text { All the outcomes defined in } \\
\text { the methods section were } \\
\text { measured and reported. }\end{array}$ & $\begin{array}{l}\text { Low Risk } \\
\text { None. }\end{array}$ \\
\hline $\begin{array}{l}\text { Unclear Risk } \\
\text { The study did not address this outcome. An email was } \\
\text { sent to the corresponding author, but there was no } \\
\text { response. }\end{array}$ & $\begin{array}{c}\text { Low Risk } \\
\text { As illustrated on the CONSORT } \\
\text { flow chart, there was no } \\
\text { missing data. }\end{array}$ & $\begin{array}{l}\text { Low Risk } \\
\text { All the outcomes defined in } \\
\text { the methods section were } \\
\text { measured and reported. }\end{array}$ & $\begin{array}{l}\text { Low Risk } \\
\text { None. }\end{array}$ \\
\hline $\begin{array}{l}\text { Unclear Risk } \\
\text { The study did not address this outcome. An email was } \\
\text { sent to the corresponding author, but there was no } \\
\text { response. }\end{array}$ & $\begin{array}{l}\text { Unclear Risk } \\
\text { The study did not address this } \\
\text { outcome. An email was sent to } \\
\text { the corresponding author, but } \\
\text { there was had no response. }\end{array}$ & $\begin{array}{l}\text { Low Risk } \\
\text { All the outcomes defined in } \\
\text { the methods section were } \\
\text { measured and reported. }\end{array}$ & $\begin{array}{l}\text { Low Risk } \\
\text { None. }\end{array}$ \\
\hline $\begin{array}{l}\text { Low Risk } \\
\text { "... were aware of the irradiation side and the results } \\
\text { were recorded by a third party." }\end{array}$ & $\begin{array}{l}\text { Unclear Risk } \\
\text { The study did not address this } \\
\text { outcome. An email was sent to } \\
\text { the corresponding author, but } \\
\text { there was no response. }\end{array}$ & $\begin{array}{l}\text { Low Risk } \\
\text { All the outcomes defined in } \\
\text { the methods section were } \\
\text { measured and reported. }\end{array}$ & $\begin{array}{l}\text { Low Risk } \\
\text { None. }\end{array}$ \\
\hline $\begin{array}{l}\text { Low Risk } \\
\text { "The distance measurement was done by the } \\
3^{\text {rd }} \text { operator, who had no knowledge about which } \\
\text { quadrant had been considered in the laser group." }\end{array}$ & $\begin{array}{l}\text { Low Risk } \\
\text { No dropouts occurred. } \\
\text { The same sample number as } \\
\text { mentioned in the methods part } \\
\text { was mentioned again in the } \\
\text { results part. }\end{array}$ & $\begin{array}{l}\text { Low Risk } \\
\text { All the outcomes defined in } \\
\text { the methods section were } \\
\text { measured and reported. }\end{array}$ & $\begin{array}{l}\text { Low Risk } \\
\text { None. }\end{array}$ \\
\hline $\begin{array}{l}\text { Low Risk } \\
\text { The measurements were performed by an examiner } \\
\text { other than the operator who applied the laser, which } \\
\text { allowed a double-blind study, as the examiner did } \\
\text { not know which side was the irradiated one when } \\
\text { performing the clinical measurements. }\end{array}$ & $\begin{array}{l}\text { Low Risk } \\
\text { No dropouts, as shown in the } \\
\text { results tables. }\end{array}$ & $\begin{array}{l}\text { Low Risk } \\
\text { All the outcomes defined in } \\
\text { the methods section were } \\
\text { measured and reported. }\end{array}$ & $\begin{array}{l}\text { Low Risk } \\
\text { None. }\end{array}$ \\
\hline $\begin{array}{l}\text { Unclear Risk } \\
\text { The study did not address this outcome. An email } \\
\text { was sent to the corresponding author, but there } \\
\text { was no response. Noteworthy, the movements were } \\
\text { measured using the Smile AnalyzerTM software; the } \\
\text { reference points were selected by one investigator } \\
\text { and confirmed by another one. }\end{array}$ & $\begin{array}{l}\text { Unclear Risk } \\
\text { The study did not address this } \\
\text { outcome. An email was sent to } \\
\text { the corresponding author, but } \\
\text { there was no response }\end{array}$ & $\begin{array}{l}\text { Low Risk } \\
\text { All the outcomes defined in } \\
\text { the methods section were } \\
\text { measured and reported. }\end{array}$ & $\begin{array}{l}\text { Low Risk } \\
\text { None. }\end{array}$ \\
\hline
\end{tabular}




\begin{tabular}{|c|c|c|c|c|}
\hline No. & Study/Setting & Selection bias (randomization) & Selection bias (allocation concealment) & Performance bias \\
\hline 19 & $\begin{array}{l}\text { Souza } \\
2014 \\
\text { Brazil } \\
\text { (thesis) }\end{array}$ & $\begin{array}{l}\text { Low Risk } \\
\text { Laser was applied randomly only in } 1 \text { of } \\
\text { the canines in the maxilla and in } 1 \text { of the } \\
\text { canines in the mandible. }\end{array}$ & $\begin{array}{l}\text { Unclear Risk } \\
\text { The study did not address this outcome. }\end{array}$ & $\begin{array}{l}\text { Low Risk } \\
\text { According to the criteria of judging the } \\
\text { risk of bias, a low risk of bias is considered } \\
\text { when the outcome is unlikely to be } \\
\text { influenced by a lack of blinding. }\end{array}$ \\
\hline 20 & $\begin{array}{l}\text { Kau et al. } \\
2013 \\
\text { USA }\end{array}$ & $\begin{array}{l}\text { Low Risk } \\
\text { "The subjects were randomized into groups } \\
\text { with varying treatment exposure times." }\end{array}$ & $\begin{array}{l}\text { Low Risk } \\
\text { It was confirmed by contacting the } \\
\text { corresponding author. }\end{array}$ & $\begin{array}{l}\text { Low Risk } \\
\text { According to the criteria of judging the } \\
\text { risk of bias, a low risk of bias is considered } \\
\text { when the outcome is unlikely to be } \\
\text { influenced by a lack of blinding. }\end{array}$ \\
\hline 21 & $\begin{array}{l}\text { Doshi-Mehta } \\
\text { and Bhad-Patill } \\
2012 \\
\text { India }\end{array}$ & $\begin{array}{l}\text { Low Risk } \\
\text { "A randomly assigned incomplete block } \\
\text { was used." }\end{array}$ & $\begin{array}{l}\text { Unclear Risk } \\
\text { The study did not address this outcome. } \\
\text { An email was sent to the corresponding } \\
\text { author, but there was no response. }\end{array}$ & $\begin{array}{l}\text { Low Risk } \\
\text { Although the participants only were } \\
\text { blinded, according to the criteria of } \\
\text { judging the risk of bias, a low risk of } \\
\text { bias is considered when the outcome } \\
\text { is unlikely to be influenced by a lack of } \\
\text { blinding. }\end{array}$ \\
\hline 22 & $\begin{array}{l}\text { Sousa et al. } \\
2011 \\
\text { Brazil }\end{array}$ & $\begin{array}{l}\text { Low Risk } \\
\text { "The laser application was performed by } \\
1 \text { operator at the predetermined point } \\
\text { areas, in only } 1 \text { of the canines randomly } \\
\text { chosen." }\end{array}$ & $\begin{array}{l}\text { Unclear Risk } \\
\text { The study did not address this outcome. } \\
\text { An email was sent to the corresponding } \\
\text { author, but there was no response. }\end{array}$ & $\begin{array}{l}\text { Low Risk } \\
\text { Although the participants only were } \\
\text { blinded, according to the criteria of } \\
\text { judging the risk of bias, a low risk of } \\
\text { bias is considered when the outcome } \\
\text { is unlikely to be influenced by a lack of } \\
\text { blinding. }\end{array}$ \\
\hline 23 & $\begin{array}{l}\text { Hosseini et al. } \\
2011 \\
\text { Iran }\end{array}$ & $\begin{array}{l}\text { Low Risk } \\
\text { "In this randomized clinical trial ...." } \\
\text { The method of randomization was not } \\
\text { mentioned. }\end{array}$ & $\begin{array}{l}\text { Low Risk } \\
\text { It was confirmed by contacting the } \\
\text { corresponding author. }\end{array}$ & $\begin{array}{l}\text { Low Risk } \\
\text { According to the criteria of judging the } \\
\text { risk of bias, a low risk of bias is considered } \\
\text { when the outcome is unlikely to be } \\
\text { influenced by a lack of blinding. }\end{array}$ \\
\hline 24 & $\begin{array}{l}\text { Limpanichkul et al. } \\
2006 \\
\text { Thailand }\end{array}$ & $\begin{array}{l}\text { Low Risk } \\
\text { "Block randomization was used to allocate } \\
\text { the side of the maxillary teeth (the left and } \\
\text { right sides) to be subjected to LLLT and the } \\
\text { placebo sides." }\end{array}$ & $\begin{array}{l}\text { Unclear Risk } \\
\text { The study did not address this outcome. } \\
\text { An email was sent to the corresponding } \\
\text { author, but there was no response. }\end{array}$ & $\begin{array}{l}\text { Low Risk } \\
\text { The participants and the clinicians } \\
\text { responsible for the treatment stages } \\
\text { were blinded. Moreover, according to } \\
\text { the criteria of judging the risk of bias, a } \\
\text { low risk of bias is considered when the } \\
\text { outcome is unlikely to be influenced by a } \\
\text { lack of blinding. }\end{array}$ \\
\hline 25 & $\begin{array}{l}\text { Cruz et al. } \\
2004 \\
\text { Brazil }\end{array}$ & $\begin{array}{l}\text { Low Risk } \\
\text { "The left and right halves of the upper } \\
\text { arcades were randomly divided into } \\
\text { the described groups. The method of } \\
\text { randomization was not described in } \\
\text { the paper. An email was sent to the } \\
\text { corresponding author, but there was no } \\
\text { response. }\end{array}$ & $\begin{array}{c}\text { Unclear Risk } \\
\text { The study did not address this outcome. } \\
\text { An email was sent to the corresponding } \\
\text { author; however, the corresponding } \\
\text { author could not give definite answers, } \\
\text { as the research had been done a long } \\
\text { time ago. }\end{array}$ & $\begin{array}{l}\text { Low Risk } \\
\text { The study did not address this outcome. } \\
\text { However, according to the criteria of } \\
\text { judging the risk of bias, a low risk of } \\
\text { bias is considered when the outcome } \\
\text { is unlikely to be influenced by a lack of } \\
\text { blinding. }\end{array}$ \\
\hline
\end{tabular}

CONSORT - Consolidated Standards of Reporting Trials; LPT - laser phototherapy.

Note: The attrition bias was considered as at: low risk if the missing data was less than $10 \%$ or less than $20 \%$, but with a balanced number and similar reasons for dropping out across the groups;

unclear risk if the missing data was between $10 \%$ and $20 \%$ with an unequal number and different reasons for dropping out across the groups; and high risk if the missing data was more than $20 \%$. 


\begin{tabular}{|c|c|c|c|}
\hline Detection bias & Attrition bias & Reporting bias & Other bias \\
\hline $\begin{array}{l}\text { Low Risk } \\
\text { The analysis was performed at least } 3 \text { months after } \\
\text { the end of the laser application with the objective } \\
\text { of the examiner not to remember which was the } \\
\text { irradiated and non-irradiated side of each patient, } \\
\text { giving the study a double-blind character. }\end{array}$ & $\begin{array}{l}\text { Low Risk } \\
\text { No dropouts, as shown in the } \\
\text { results tables. }\end{array}$ & $\begin{array}{l}\text { Low Risk } \\
\text { All the outcomes defined in } \\
\text { the methods section were } \\
\text { measured and reported. }\end{array}$ & $\begin{array}{l}\text { Low Risk } \\
\text { None. }\end{array}$ \\
\hline $\begin{array}{l}\text { Low Risk } \\
\text { Assessor blinding was achieved, as confirmed by the } \\
\text { corresponding author. }\end{array}$ & $\begin{array}{l}\text { Low Risk } \\
\text { No dropouts, as confirmed by } \\
\text { the corresponding author. }\end{array}$ & $\begin{array}{l}\text { Low Risk } \\
\text { All the outcomes defined in } \\
\text { the methods section were } \\
\text { measured and reported. }\end{array}$ & $\begin{array}{l}\text { Low Risk } \\
\text { The trial was sponsored by } \\
\text { Biolux Research. This company } \\
\text { manufactures the devices } \\
\text { used in this clinical trial. The } \\
\text { authors did not state clearly } \\
\text { that sponsors had no role in } \\
\text { the design or execution of this } \\
\text { study. }\end{array}$ \\
\hline $\begin{array}{l}\text { Low Risk } \\
\text { "The measurement recorder was blinded to the } \\
\text { experimental and control sides." }\end{array}$ & $\begin{array}{l}\text { Unclear Risk } \\
\text { The study did not address this } \\
\text { outcome. An email was sent to } \\
\text { the corresponding author, but } \\
\text { there was no response }\end{array}$ & $\begin{array}{l}\text { Low Risk } \\
\text { All the outcomes defined in } \\
\text { the methods section were } \\
\text { measured and reported. }\end{array}$ & $\begin{array}{l}\text { Low Risk } \\
\text { None. }\end{array}$ \\
\hline $\begin{array}{l}\text { Low Risk } \\
\text { "Both the patient and the evaluators were not } \\
\text { informed which tooth was irradiated." }\end{array}$ & $\begin{array}{l}\text { Unclear Risk } \\
\text { The study did not address this } \\
\text { outcome. An email was sent to } \\
\text { the corresponding author, but } \\
\text { there was no response }\end{array}$ & $\begin{array}{l}\text { Low Risk } \\
\text { All the outcomes defined in } \\
\text { the methods section were } \\
\text { measured and reported. }\end{array}$ & $\begin{array}{l}\text { Low Risk } \\
\text { None. }\end{array}$ \\
\hline $\begin{array}{l}\text { Low Risk } \\
\text { It was confirmed by contacting the corresponding } \\
\text { author. }\end{array}$ & $\begin{array}{l}\text { Low Risk } \\
\text { The missing data was less than } \\
\text { 20\% (8\%). }\end{array}$ & $\begin{array}{l}\text { Low Risk } \\
\text { All the outcomes defined in } \\
\text { the methods section were } \\
\text { measured and reported. }\end{array}$ & $\begin{array}{l}\text { Low Risk } \\
\text { None. }\end{array}$ \\
\hline $\begin{array}{l}\text { Unclear Risk } \\
\text { The study did not address this outcome. An email was } \\
\text { sent to the corresponding author, but there was no } \\
\text { response. }\end{array}$ & $\begin{array}{l}\text { Unclear Risk } \\
\text { The study did not address this } \\
\text { outcome. An email was sent to } \\
\text { the corresponding author, but } \\
\text { there was no response. }\end{array}$ & $\begin{array}{l}\text { Low Risk } \\
\text { All the outcomes defined in } \\
\text { the methods section were } \\
\text { measured and reported. }\end{array}$ & $\begin{array}{l}\text { Low Risk } \\
\text { None. }\end{array}$ \\
\hline $\begin{array}{l}\text { Unclear Risk } \\
\text { The study did not address this outcome. An email } \\
\text { was sent to the corresponding author; however, the } \\
\text { corresponding author could not give definite answers, } \\
\text { as the research had been done a long time ago. }\end{array}$ & $\begin{array}{l}\text { Unclear Risk } \\
\text { The study did not address this } \\
\text { outcome. An email was sent } \\
\text { to the corresponding author; } \\
\text { however, the corresponding } \\
\text { author could not give definite } \\
\text { answers, as the research had } \\
\text { been done a long time ago. }\end{array}$ & $\begin{array}{l}\text { Low Risk } \\
\text { All the outcomes defined in } \\
\text { the methods section were } \\
\text { measured and reported. }\end{array}$ & $\begin{array}{l}\text { Low Risk } \\
\text { None. }\end{array}$ \\
\hline
\end{tabular}




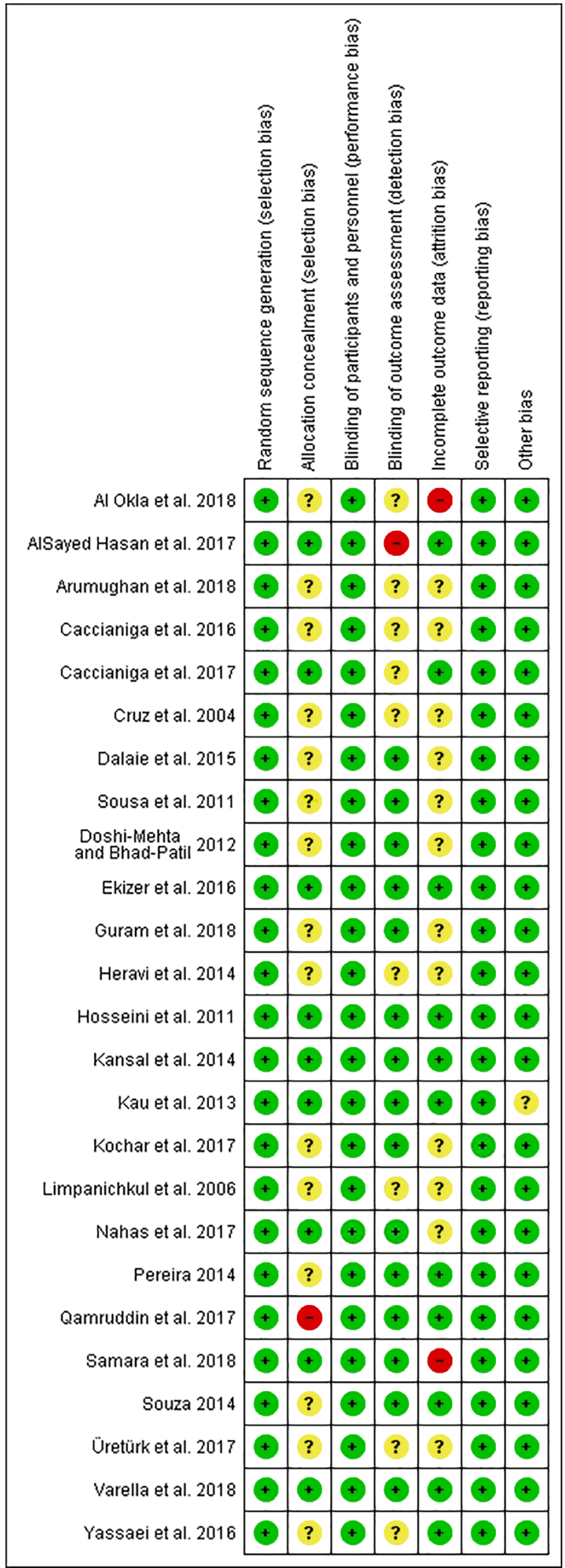

Fig. 4. Risk of bias summary: The review authors'judgments about each item of the risk of bias for the studies included

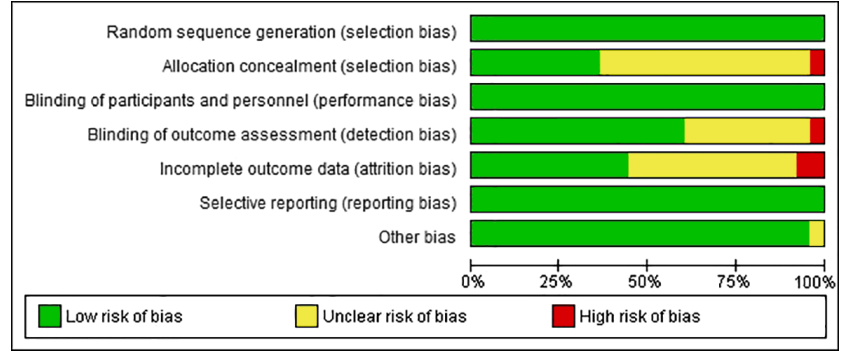

Fig. 5. Risk of bias graph: The review authors'judgments about each item of the risk of bias, presented as percentages across all the studies included

Although relevant grey literature, dissertations and non-English RCTs were sought in order to reduce the potential for the publication bias, the resultant asymmetrical funnel plots might be affected by the significant heterogeneity presented among the included studies.

It is worth highlighting that reporting the total number of joules applied per time period rather than $\mathrm{J} / \mathrm{cm}^{2}$ is recommended for expressing the laser dosage in $\mathrm{fu}$ ture trials. This recommendation is clinically important, as it allows a precise comparison between different protocols, and thus allows avoiding confusion. To illustrate this, Kochar et al. and Cruz et al. used the same energy density $\left(5 \mathrm{~J} / \mathrm{cm}^{2}\right)$, but the total amount of energy applied was $30 \mathrm{~J} / \mathrm{month}$ and $8 \mathrm{~J} / \mathrm{month}$, respectively. ${ }^{16,27}$ Adding to the confusion, Guram et al. used $5 \mathrm{~J} / \mathrm{cm}^{2}$, whereas Limpanichkul et al. used $25 \mathrm{~J} / \mathrm{cm}^{2}$, but calculating the total amount of energy applied resulted in $48 \mathrm{~J} / 3$ weeks and $55.2 \mathrm{~J} /$ month, respectively. ${ }^{14,26}$ This means the systematic review results of Ge et al., where 5 and $8 \mathrm{~J} / \mathrm{cm}^{2}$ were reported to be more effective than 20 and $25 \mathrm{~J} / \mathrm{cm}^{2}$, constitute a misleading way of comparing different study protocols. ${ }^{7}$

Finally, the methodology of the studies utilizing physical stimuli was mostly affected by incomplete outcome data (attrition bias). Applying physical stimulation requires a highly compliant patient, who is actively interested in a shorter orthodontic treatment. Laser protocols often involve laser applications at several daily appointments, which requires high compliance to ensure efficacy.

As with all reviews, ours has strengths and limitations. With regard to strengths, we applied an extensive electronic search, sought grey literature, dissertations and non-English references, checked ongoing registered trials, used the Cochrane Collaboration tool for the assessment of the risk of bias, assessed the publication bias, and finally rated the overall evidence quality using the GRADE criteria. We tried to group LLLT studies according to the total number of joules applied per month, but there was no similarity among the studies in terms of the dosage used. Therefore, a wide variety of LLLT dosimetry in the included studies is considered a limitation of this systematic review. 

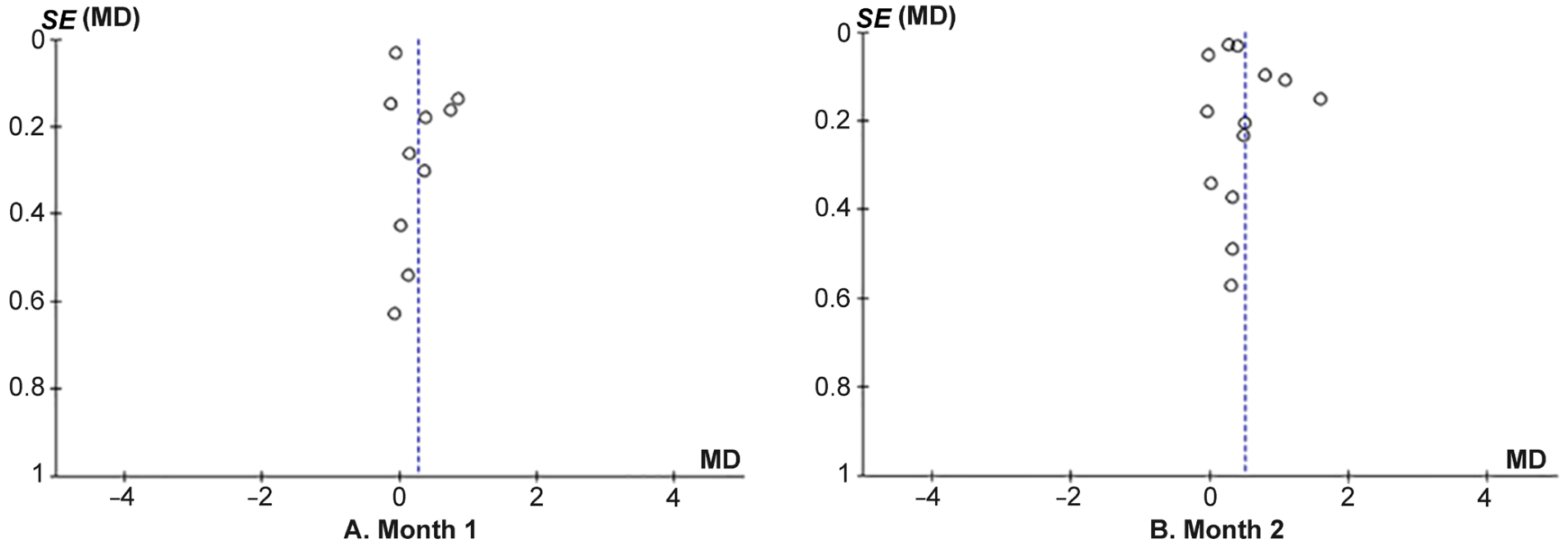

Fig. 6. Funnel plots of the effect estimate against standard error (SE)

A - month 1 of upper canine retraction facilitated by LLLT; B - month 2 of upper canine retraction facilitated by LLLT.

\section{Conclusions}

Low-level laser therapy can speed up the rate of the orthodontic tooth movement, and consequently decrease the treatment time. However, the quality of evidence ranged from low to very low and the clinical significance is questionable, so more precise studies are needed. It is highly recommended to express and compare the laser dosage in future trials by the total number of joules applied per time period rather than the previously used $\mathrm{J} / \mathrm{cm}^{2}$.

\section{ORCID iDs}

Wesam Mhd Mounir Bakdach (1) https://orcid.org/0000-0001-6523-0075 Rania Hadad (1) https://orcid.org/0000-0002-8426-143X

\section{References}

1. Roscoe MG, Meira JB, Cattaneo PM. Association of orthodontic force system and root resorption: A systematic review. Am J Orthod Dentofacial Orthop. 2015;147(5):610-626.

2. Tsichlaki A, Chin SY, Pandis N, Fleming PS. How long does treatment with fixed orthodontic appliances last? A systematic review. Am J Orthod Dentofacial Orthop. 2016;149(3):308-318.

3. Talic NF. Adverse effects of orthodontic treatment: A clinical perspective. Saudi Dent J. 2011;23(2):55-59.

4. Huang H, Williams RC, Kyrkanides S. Accelerated orthodontic tooth movement: Molecular mechanisms. Am J Orthod Dentofacial Orthop. 2014;146(5):620-632.

5. Yoshida T, Yamaguchi $M$, Utsunomiya $T$, et al. Low-energy laser irradiation accelerates the velocity of tooth movement via stimulation of the alveolar bone remodeling. Orthod Craniofac Res. 2009;12(4):289-298.

6. Doshi-Mehta G, Bhad-Patil WA. Efficacy of low-intensity laser therapy in reducing treatment time and orthodontic pain: A clinical investigation. Am J Orthod Dentofacial Orthop. 2012;141(3):289-297.

7. Ge MK, He WL, Chen J, et al. Efficacy of low-level laser therapy for accelerating tooth movement during orthodontic treatment: $A$ systematic review and meta-analysis. Lasers Med Sci. 2015;30(5):1609-1618.

8. de Almeida VL, de Andrade Gois VL, Andrade RN, et al. Efficiency of low-level laser therapy within induced dental movement: A systematic review and meta-analysis. $J$ Photochem Photobiol $B$. 2016;158:258-266.
9. Imani MM, Golshah A, Safari-Faramani R, Sadeghi M. Effect of lowlevel laser therapy on orthodontic movement of human canine: A systematic review and meta-analysis of randomized clinical trials. Acta Inform Med. 2018;26(2):139-143.

10. AlSayed Hasan MMA, Sultan K, Hamadah O. Low-level laser therapy effectiveness in accelerating orthodontic tooth movement: A randomized controlled clinical trial. Angle Orthod. 2017;87(4):499-504.

11. Caccianiga $G$, Paiusco $A$, Perillo $L$, et al. Does low-level laser therapy enhance the efficiency of orthodontic dental alignment? Results from a randomized pilot study. Photomed Laser Surg. 2017;35(8):421-426.

12. Al Okla N, Bader DM, Makki L. Effect of photobiomodulation on maxillary decrowding and root resorption: A randomized clinical trial. APOS Trends Orthod. 2018;8(2):86-91.

13. Varella AM, Revankar AV, Patil AK. Low-level laser therapy increases interleukin-1 $\beta$ in gingival crevicular fluid and enhances the rate of orthodontic tooth movement. Am J Orthod Dentofacial Orthop. 2018;154(4):535-544.

14. Guram G, Reddy RK, Dharamsi AM, Ismail PM, Mishra S, Prakashkumar MD. Evaluation of low-level laser therapy on orthodontic tooth movement: A randomized control study. Contemp Clin Dent. 2018;9(1):105-109.

15. Qamruddin I, Alam MK, Mahroof V, Fida M, Khamis MF, Husein A. Effects of low-level laser irradiation on the rate of orthodontic tooth movement and associated pain with self-ligating brackets. Am J Orthod Dentofacial Orthop. 2017;152(5):622-630.

16. Kochar GD, Londhe SM, Varghese B, Jayan B, Kohli S, Kohli VS. Effect of low-level laser therapy on orthodontic tooth movement. JIndian Orthod Soc. 2017;51(2):81-86.

17. Üretürk SE, Saraç M, Fıratlı S, Can ŞB, Güven Y, Fıratlı E. The effect of low-level laser therapy on tooth movement during canine distalization. Lasers Med Sci. 2017;32(4):757-764.

18. Yassaei S, Aghili H, Afshari JT, Bagherpour A, Eslami F. Effects of diode laser $(980 \mathrm{~nm}$ ) on orthodontic tooth movement and interleukin 6 levels in gingival crevicular fluid in female subjects. Lasers Med Sci. 2016;31(9):1751-1759.

19. Dalaie K, Hamedi R, Kharazifard MJ, Mahdian M, Bayat M. Effect of low-level laser therapy on orthodontic tooth movement: A clinical investigation. J Dent (Tehran). 2015;12(4):249-256.

20. Kansal A, Kittur N, Kumbhojkar V, Keluskar KM, Dahiya P. Effects of low-intensity laser therapy on the rate of orthodontic tooth movement: A clinical trial. Dent Res J (Isfahan). 2014;11(4):481-488.

21. Heravi F, Moradi A, Ahrari F. The effect of low level laser therapy on the rate of tooth movement and pain perception during canine retraction. Oral Heal Dent Manag. 2014;13(2):183-188. 
22. Pereira SC da C. Influência do laser de baixa intensidade na movimentação ortodôntica-avaliação clínica e radiográfica (doctoral thesis) [in Portuguese]. Universidade de São Paulo, Brazil, 2014.

23. Souza JMS de. Avaliação da influência do laser de baixa intensidade na movimentação ortodôntica e supressão da dor (doctoral thesis) [in Portuguese]. Universidade de São Paulo, Brazil, 2014.

24. Sousa MV, Scanavini MA, Sannomiya EK, Velasco LG, Angelieri F. Influence of low-level laser on the speed of orthodontic movement. Photomed Laser Surg. 2011;29(3):191-196.

25. Hosseini MH, Mahmoodzadeh Darbandi M, Kamali A. Effect of low level laser therapy on orthodontic movement in human [in Persian]. J Dent Med. 2011;24(3):156-164.

26. Limpanichkul W, Godfrey K, Srisuk N, Rattanayatikul C. Effects of low-level laser therapy on the rate of orthodontic tooth movement. Orthod Craniofac Res. 2006;9(1):38-43.

27. Cruz DR, Kohara EK, Ribeiro MS, Wetter NU. Effects of low-intensity laser therapy on the orthodontic movement velocity of human teeth: A preliminary study. Lasers Surg Med. 2004;35(2):117-120.

28. Samara SA, Nahas AZ, Rastegar-Lari TA. Velocity of orthodontic active space closure with and without photobiomodulation therapy: A single-center, cluster randomized clinical trial. Lasers Dent Sci. 2018;2(2):109-118.

29. Arumughan S, Somaiah S, Muddaiah S, Shetty B, Reddy G, Roopa S. A comparison of the rate of retraction with low-level laser therapy and conventional retraction technique. Contemp Clin Dent. 2018;9(2):260-266.

30. Nahas AZ, Samara SA, Rastegar-Lari TA. Decrowding of lower anterior segment with and without photobiomodulation: A single center, randomized clinical trial. Lasers Med Sci. 2017;32(1):129-135.

31. Kau CH, Kantarci A, Shaughnessy T, et al. Photobiomodulation accelerates orthodontic alignment in the early phase of treatment. Prog Orthod. 2013;14:30.

32. Ekizer A, Türker G, Uysal T, Güray E, Taşdemir Z. Light emitting diode mediated photobiomodulation therapy improves orthodontic tooth movement and miniscrew stability: A randomized controlled clinical trial. Lasers Surg Med. 2016;48(10):936-943.

33. Caccianiga G, Crestale $C$, Cozzani $M$, et al. Low-level laser therapy and invisible removal aligners. J Biol Regul Homeost Agents. 2016;30(2 Suppl 1):107-113. 